\title{
Ortaçă̆ İslam Mimarisi Süsleme Programında Kakma Tekniği: Mardin Örneği
}

\section{Evindar Yeşilbaş*}

Atıf/@: Yeşilbaş, Evindar, Ortaçağ İslam Mimarisi Süsleme Programında Kakma Tekniği: Mardin Örneği, Artuklu Akademi 2020/ 7 (1), 29-76.

Öz.: Mimari süsleme, kullanılan malzemenin yüzeyine uygulanan müdahaleye bağlı olarak farklı tekniklerle karşımıza çıkmaktadır. Mimari yapılarda ana malzeme olarak yüzyıllardır en çok kullanılan taş, coğrafi etkenlerin ve dayanıklılı̆̆ın yanında kişisel beğeni sonucunda da tercih edilmiştir. Mimaride taşa uygulanan süslemelerde oyma, kafes oyma, kakma, kazıma, boyama teknikleri ile renkli taş kullanımından söz edilebilir. Çalışmamıza konu olan kakma tekniği, ana inşa malzemesi üzerine farklı renkteki malzemenin kakılması ile oluşturulan bir tekniktir. Bu çalışmada, Mardin'in İslamî dönem dinî yapılarından kakma tekniği süslemeye sahip Latifiye Camii, Hamza-i Kebir Camii, Zinciriye Medresesi ve Kasımiye Medresesi incelenmektedir. Bu çalışmadaki amacımız, kakma tekniği konusunda alana katkı sağlamakla birlikte Mardin'deki ortaçağ İslamî dönem dinî yapılarında görülen kakma teknikli süslemeleri detaylarıyla literatüre kazandırmaktır. Anadolu'da aynı dönem içerisinde karşılaştı̆̆ımız örneklere nazaran, Mardin'de daha yoğun kullanılan bu teknik, motif ve kompozisyonlarda Selçuklu süsleme üslubunun izlerini taşımaktadır.

Anahtar Kelimeler: Mimari, Mardin, süsleme, kakma tekniği

\section{Marquetry Technique in Medieval Islamic Architecture Decoration Program: The Sample of Mardin}

Citation/৫: Yeşilbaş, Evindar, Marquetry Technique in Medieval Islamic Architecture Decoration Program: The Sample of Mardin, Artuklu Akademi 2020/ 7 (1), 29-76.

\begin{abstract}
Architectural decoration techniques vary according to the intervention applied on the building material surface. Stone has been used as a main building material for centuries not only due to geographical factors and durability, but also due to personal taste. Embossment, engraving, tracery, marquetry,
\end{abstract}

\footnotetext{
Doç. Dr., Mardin Artuklu Üniversitesi Edebiyat Fakültesi Sanat Tarihi Bölümü,
} evindaryesilbas@artuklu.edu.tr. 


\begin{abstract}
damascene etching and engraining methods, and coloured stones are used for stone decoration in architecture. Marquetry, which is the subject of our study, is a technique used to create decorative patterns by inserting materials of different colours on the building material. This study focused on Islamic period historic buildings embodying stone-marquetry decorations in Mardin, such as Latifiye Mosque, Hamza-i Kebir Mosque, Zinciriye Madrasa and Kasımiye Madrasa. The objective of this study is to fill the gap in the literature on marquetry and to provide insight into the marquetry decorations of medieval Islamic buildings in Mardin. In comparison to the other architectural structures built in the same period in Anatolia, the marquetry decorations in the architectural structures in Mardin reflect more the characteristics of the Seljuk decoration style in motifs and compositions.
\end{abstract}

Key Words: Architecture, Mardin, decoration, stone, marquetry technique

\title{
Giriş
}

Kakma tekniği, maden, ahşap, fildişi, bağa, mermer vb. malzeme üzerine motifin şekline göre yuvaların açılması ve açılan yuvalara farklı veya aynı cins malzemeden kesilmiş parçaların yerleştirilmesi ile ortaya çıkan bir süsleme türüdür. Arapça karşıllı̆ı, tarsi', tekfit ve tet'îm kelimeleriyle karşılanmakta ve kıymetli taşlarla süslenmiş eserler için de murassa' tabiri kullanılmaktadır. Osmanlılarda tekniğin uygulandığı malzemeye göre bu işi yapan ustalar, farklı adlarla anılmışlardır. Kakmacılıkta sedef işiyle uğraşan ustalara "sedefkâr" denilirken metal üzerine kakma işiyle uğraşanlara ise " zernişânciyan, kûftkârî, kaffâtîn" gibi değişik adlar verilmiştir. ${ }^{1}$

Tekniğin uygulanmasında, kompozisyonu oluşturan motifler için malzemenin yüzeyine yuvalar oyulur. Böylece ortaya çıkan yuvanın içine motife göre kesilmiş parça, tokmaklar veya çekiçler yardımıyla yerleştirilir. Kakma motifin yüzeyine kazıma, oyma tekniğiyle herhangi bir desen önce veya daha sonra da işlenebilir. Teknikteki işlem sırasından da anlaşıldığ 1 üzere, temelde iki teknik arka arkaya kullanılmaktadır. Illk aşamada kakma uygulanacak yüzey, oyma tekniği ile şekillendirilmekte, daha sonra oyulan kısımların motifine göre ayrı bir malzeme hazırlanarak yüzeye tatbik edilmektedir.

Kakma tekniği, el sanatlarında daha çok uygulanmakla birlikte, mimari süslemede de uygulanmıştır. ${ }^{2}$ Mimari ile ilişkili el sanatlarından özellikle

Nebi Bozkurt, "Kakmacılık", Türkiye Diyanet Vakfı İslam Ansiklopedisi, (İstanbul: Türkiye Diyanet Vakfı, 2001), 24, 216-219.

2 El sanatlarında daha çok tercih edilen bu teknik, ahşap, metal, cilt, kuyumculuk örnekleri ile sıkça karşımıza çıkmaktadır. 
ahşap işlerinden vaiz kürsüsü, rahle, kapı ve pencere kanatları vb. örneklerde kakma tekniği sıkça kullanılmıştır. Taş süslemede ise oyma, kazıma, boyama teknikleri ile renkli taş süsleme uygulamalarından söz edilebilir. Bu tekniklerin birçoğunun bir arada uygulandığı da görülmüştür. Renkli taş süsleme olarak değerlendirilen kakma tekniğinin uygulamasında, malzeme olarak daha çok birbiri ile zit etki yaratacak nitelikte uygun ölçülerde biçimlenmiş taş, mermer, çini vb. bir malzeme tercih edilmiştir. Mimari süslemede, coğrafi etkenlerin ve dayanıklılığın yanında kişisel beğenin de etkisiyle, yüzyıllardır tercihen en fazla taş malzemenin kullanılmıştır.

Anadolu topraklarında tarihin erken dönemlerinden Osmanlı Geç dönemine kadar küçük el sanatlarından mimari süslemeye kadar geniş bir uygulama alanına sahip olan bu teknik, Anadolu ölçeğinde mimari süsleme bakımından münferit bazı çalışmalar dışında, detaylı bir anlatımla akademik çalışmalara yeteri kadar konu olmamıştır. ${ }^{3}$ Literatür araştırmasında 4 Mardin'deki eserlerin de daha çok toplu çalışmalara ${ }^{5}$, kısmen de münferit

3 Mimari süslemeye yönelik çalışmaların daha genel bir yaklaşımla, dönemsel veya bölgesel sınırlamalarla taş süsleme, taç kapı, mihrap gibi yapı elemanları veya kent ölçeğinde mimari eserler üzerine yoğunlaştığı görülmektedir. Bu çalışmalarda süsleme programlarında karşılaşılan kakma teknikleri ifade edilmekle birlikte, ayrı bir çalışma olarak kakma tekniğinin ele alınmadığı dikkati çekmektedir. Söz konusu çalışmaların bazıları şunlardır; Yıldıray Özbek, Osmanlı Beyliği Mimarisinde Taş Süsleme (1300-1453), bs. (Ankara: Kültür Bakanlığı Yayınları, 2002); Metin Sözen, Anadolu Medreseleri I. bs. (İstanbul: İstanbul Teknik Üniversitesi, Mimarlık Fakültesi Yayınları,1970); Güner İnal, “Orta Çağlarda Anadolu’da Çalışan Suriye ve Mezopotamyalı Sanatçılar", Sanat Tarihi Yıllı̆̆ı, XI: 83- 94. (1982); Gönül Öney; İlker Erginsoy, Anadolu Selçuklu Mimari Süslemesi ve El Sanatları, bs. (Ankara: İş Bankası Yayınları, 1992; Şakir Çakmak, Erken Dönem Osmanlı Mimarisinde Taçkapılar (1300-1500). bs. (Ankara: Kültür Bakanlığı Yayınları, 2001), Ömür Bakırer, Onüç ve Ondördüncü Yüzyıllarda Anadolu Mihrapları. bs. (Ankara: Türk Tarih Kurumu Yayınları, 1976); Semra Ögel, Anadolu Selçukluları'nın Taş Tezyinatı. bs. (Ankara: Türk Tarih Kurumu Basımevi, 1966); Semra Ögel, "Taç kapılar". Anadolu Selçukluları ve Beylikler Dönemi Uygarlığı 2.ed. Ali Uzay Peker ve Kenan Bilici, bs. ( Ankara: Kültür ve Turizm Bakanlığı Yayınları, 2006), 469- 486, Rahmi Hüseyin Ünal, Osmanlı Öncesi Anadolu-Türk Mimarisinde Taç Kapılar, bs. (İzmir: Ege Üniversitesi Yayınları, 1982); Orhan Cezmi Tuncer, "Birkaç Selçuklu Taç Kapısında Geometrik Araştırmalar", Vakıflar Dergisi, 16, (1982), 61-76; Ara Altun, Anadolu'da Artuklu Devri Türk Mimarisi'nin Gelişmesi, bs.( İstanbul: Kültür Bakanlığı Yayınları, 1978); A. Süheyl Ünver, Mardin Mimari Anıtlarında Tezyini Yorumlar. bs. ( İstanbul: Numune Matbaacılık, 2010); Şükriye Karadaş, Anadolu Selçuklu Dönemi Mimarisinde Bitkisel Bezeme Unsûrları, (Yayımlanmamış Doktora Tezi, Atatürk Üniversitesi, Sosyal Bilimler Enstitüsü, Erzurum 201); Ayla Ödekan, Osmanlı Öncesi Anadolu Türk Mimarisinde Mukarnash Portal Örtüleri. bs. (İstanbul: İstanbul Teknik Üniversitesi Yayınları, 1977).

4 Literatür çalışmamız, çalışmanın konusu gereği mimari süsleme ve taşa uygulanan kakma tekniği ile sınırlı kalmıştır.

5 Ara Altun, "Mardin' de Türk Devri Anıtsal Mimarisine Genel Bakış", Taşın Belleği Mardin, bs. (İstanbul: Yap1 Kredi Yayınları, 2005): 149-175.; Altun, Anadolu'da Artuklu Devri Türk Mimarisi'nin Gelişmesi; Ara Altun, Mardinde’ki Türk Devri Mimarisi. bs. (İstanbul: Mardin Valiliği Yayınları, 2011); Albert Gabriel, Şarki Türkiye'de Arkeolojik Geziler, çev: İdil Çetin (Ankara: Dipnot Kitapları 2014); Abdülgani Bulduk, Mardin Tarihi, haz. Burhan Zengin (Ankara: GAP Yayınları, 1999); Çimen Turan, Artuklu Dönemi Tarihi Yapılarındaki Figürlü Süslemeler Ve Orta Asya Kültürünün Etkileri, Yayınlanmamış Yüksek Lisans Tezi, Batman Üniversitesi Sosyal Bilimler Enstitüsü, Batman 2014; Hüseyin Karaçam, Artuklu Kitabeleri ( 1102-1409), (Yayımlanmamış Yüksek Lisans Tezi, Marmara Üniversitesi Türkiyat Araştırmaları Enstitüsü, İstanbul 2012); Murat Çağlayan, Mardin Ortaçă̆ Anttları ve Yapım Teknikleri, bs.(İstanbul: Hiper Yayın, 2017); Keppel Archibald Cameron, Creswell, "Mardin and Diyarbekr" , In Muqarnas XV: An Annual on the Visual Culture of the Islamic World, ed. Gülru Necipoglu, (Leiden: E.J. Brill,1998), 2-8; Abdüsselam Uluçam, "İslam Dönemi Mardin'i", Taşın Belleği Mardin, bs.(İstanbul: Yapı Kredi Yayınları, 2005). 99-116. 
bazı çalışmalara ${ }^{6}$ konu olduğu dikkati çekmiştir. ${ }^{7}$ Çalışmamızın konusunu, Mardin Ortaçağ İslam dönemi dini yapılarından kakma tekniğine sahip örnekler oluşturmaktadır. Bu amaç doğrultusunda, Mardin'deki Ortaçağ İslam dönemine ait eserler, tek tek incelenerek kakma teknikli süslemeye sahip olanlar, fotoğraflarla kayıt altına alınmıştır. Süslemelerde karşılaştı̆̆ımız bazı motiflerin çizimleri de ayrıca yapılmıştır.

Alan araştırmasında, Artuklu ve Akkoyunlu Devri eserlerinden Latifiye Camii, Hamza-i Kebir Camii, Zinciriye Medresesi ve Kasımiye Medresesi'nin kakma tekniği süslemelere sahip olduğu görülmüştür. Bundan dolayı sadece söz konusu yapılar, çalışma kapsamına alınmıştır. Çalışmada eserler, dönemlerine göre kendi içinde kronolojik sırayla sunulmuştur. Yapıların kısaca mimari özellikleri verildikten sonra süsleme repertuvarında kakma tekniğinin kullanıldığı bölümler, desen ve motif bağlamında detaylı bir şekilde anlatılmıştır. ${ }^{8}$ Karşılaştırma ve Değerlendirme bölümde, eserlerin öncelikle birbiriyle ve farklı bölgelerdeki benzerleri ile karşılaştırmaları yapılmıştır. Çalışmadaki anlatımlar, çok sayıda fotoğraf ve bazı motiflerin çizimleri ${ }^{9}$ ile desteklenmiştir.

Mardin'de kakma tekniğinin kullanıldığı yapıların detaylı anlatımlarına geçmeden önce bu tekniğin tarihte ilk kullanım alanlarını hatırlamak faydalı olacaktır.

Abdulkadir Yuvalı, “Artukoğulları Döneminde Mardin'deki Maddi Kültür Unsurları”, I. Uluslararası Mardin Tarihi Sempozyumu, ed. İbrahim Özçoşar, Hüseyin Haşimi Güneş, Mardin Valiliği, (Mardin 2008), II, 34; Evindar Yeşilbaş, "Hamza-i Kebir Türbesi Üzerine Yeni Değerlendirmeler", Milel ve Nihal, 2, (2014),163-182; Özlem Atalan, “Artuklu Mimarisi'nin Anıtsal Mimarisinin Korunması Üzerine Model Yaklaşımı: Kasımiye Medresesi Örneği”, I. Uluslararası Artuklu Sempozyumu Bildirileri, 25-26-27 Ekim 2007 Mardin, ed. İbrahim Özçoşar, Mardin Valiliği, (Mardin 2008), II, 307; Sultan Çaça, Mardin'de Artuklu Dönemine Ait Bir Medrese: Zinciriye (Sultan İsa) Medresesi. (Yayımlanmamış Yüksek Lisans Tezi, Sakarya Üniversitesi Sosyal Bilimler Enstitüsü , Sakarya 2013), 181; Hatice Örcün Barışta, "Mardin Kasımiye ve Zinciriye Medreselerinin Taş Süslemelerinde Gözlenen Benzerlikler", I. Uluslararası Artuklu Sempozyumu Bildirileri, 25-26-27 Ekim 2007 Mardin, ed. İbrahim Özçoşar, Mardin Valiliği, (Mardin 2008), II, 244; Murat Çağlayan, Gülsün Tanyeli, "Mardin Zinciriye (Sultan İsa) Medresesi ve Osmanlıdan Günümüze Medresedeki Restorasyon Müdahaleleri", Mimarist, 55, ( 2016): 89-93; Murat Çağlayan, Mardin Anıtsal Yapılarında Değişmişlik Ve Özgünlük Sorunları, (Yayımlanmamış Doktora Tezi, İstanbul Teknik Üniversitesi, İstanbul 2017); Murat Çağlayan, "Anadolu'da Bir Akkoyunlu Kültür Mirası: Mardin Kasımiye Medresesi", International Conference on Natural Science and Engineering (ICNASE'16) , 19-20 Mart 2016, ed. Murat Ceyhan, ( Kilis: Mavi Kitap Yayıncılık, 2016), 1113-1146; Murat Çağlayan, "Bir Mimari Karşılaştırma: Mardin Zinciriye ve Kasımiye Medreseleri”, İlk Çağlardan Modern Döneme Tarihten İzler II, ed. M. Doğan Karaçoşkun ve Osman Köse, (Ankara: Berikan Yayınevi, 2018), 147-163; İbrahim Artuk, "Mardin Zinciriye Medresesi ve Bânisi", Selçuklu Araştırmalan Dergisi, III, (1971): 191-194.

7 Abdulkadir Saylan süsleme ile ilgili hazırladığı yüksek lisans tezinde Artuklu dönemi camilerinin süslemelerini teknikten ziyade konularına göre değerlendirmiştir, bkz., Abdulkadir Saylan, Artuklu Dönemi Camilerindeki Bezemeler. (Yayımlanmamış Yüksek Lisans Tezi, Erzurum Atatürk Üniversitesi, Erzurum 2014).

8 Yapılarda görülen diğer süsleme özellikleri, çalışma kapsamına girmediği için ayrıca anlatılmaya gerek görülmemiştir.

9 Çizimler, Yüksek Mimar M. Şakir Güler'e aittir. 
Kültürel süreklilikle bugün modern sanat üretiminde dahi yeni yorumlarla kullanılan kakma tekniğinin, tarihte bilinen ilk kullanımı, yine Mardin'de karşımıza çıkmaktadır. Dargeçit'te Boncuklu Tarla Kazı çalışmaları ile ortaya çıkarılan küçük buluntular, en erken örnekler sayılabilir. ${ }^{10} \mathrm{Bu}$ parçalardan birinde fildişi plaka üzerine stilize bir akrep motifi (Fotoğraf 1) ile küpe olduğu düşünülen diğer buluntunun üst yüzeyi oyularak yerleştirilen daire motifinin renkli taşlarla oluşturulduğu görülmektedir (Fotoğraf 2). Her iki örnek de insanoğlunun, yaklaşık 11 bin yıl önce bile yerleşik hayata geçtiği ilk dönemlerde kullanacağı eşyayı süslerken farklı bir etki yaratma kaygısı taşıyarak kakma tekniğini uyguladıklarını göstermesi bakımından dikkate değerdir.

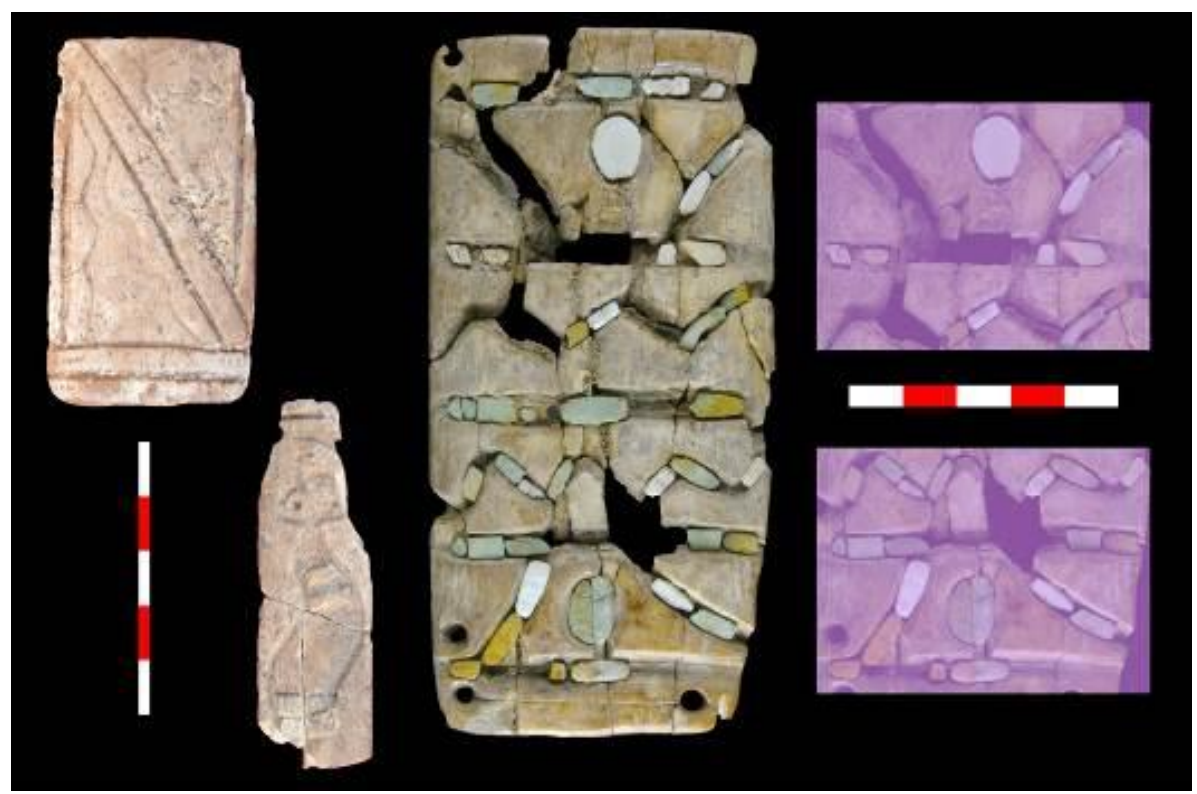

Fotoğraf 1. Boncuklu Tarla Kazılarında ortaya çıkan kakma teknikli fildişi plaka ( E. Kodaş, 2019)

10 Ergül Kodaş "Yukarı Dicle' de Yeni Bir Çanak Çömleksiz Neolitik Yerleşim Yeri: Boncuklu Tarla Kazıları ve İlk Gözlemler". Arkeoloji Ve Sanat Dergisi, 157-158, (2019): 7-20. 


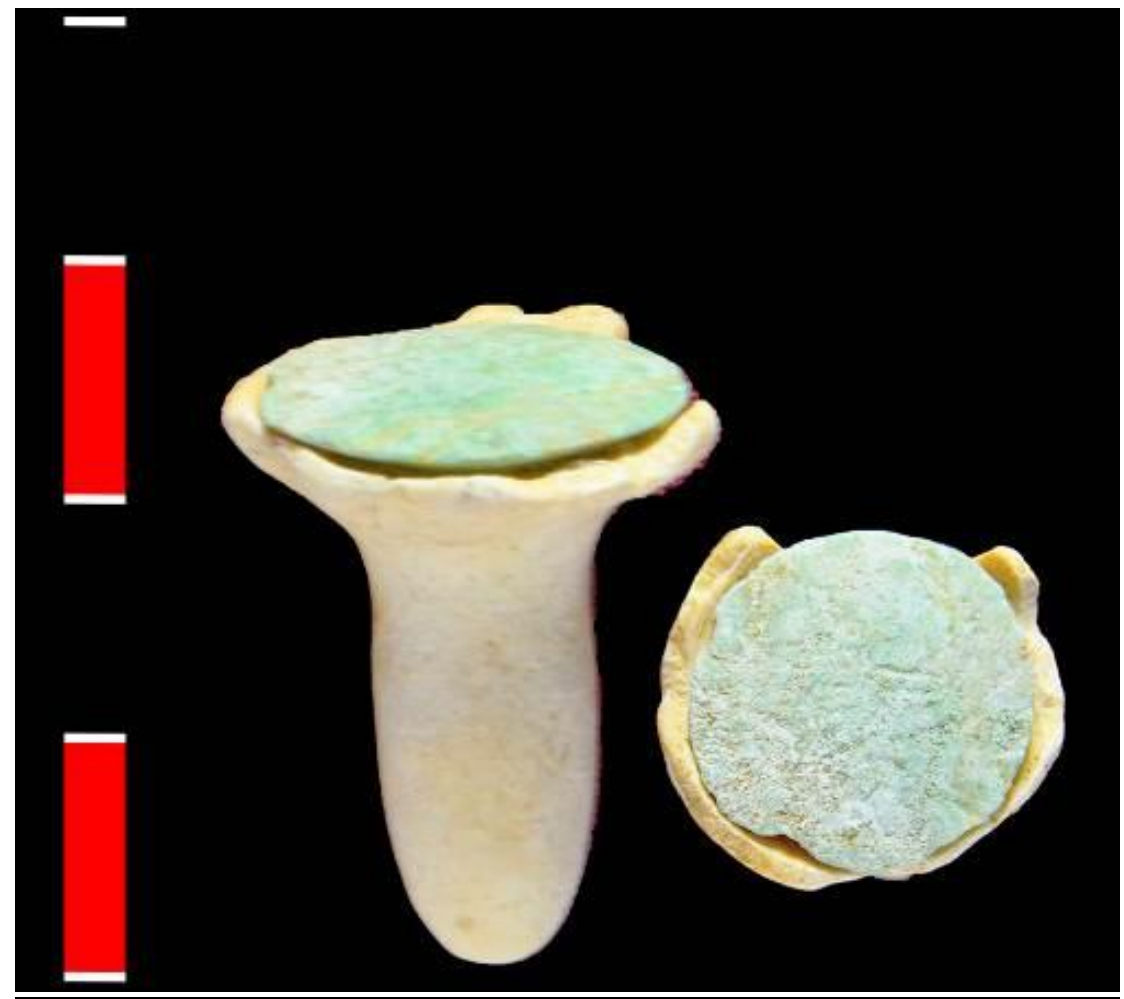

Fotoğraf 2. Boncuklu Tarla Kazılarında ortaya çıkan kakma teknikli küpe (E. Kodaş, 2019)

Günümüze ulaşan çeşitli örneklerden hareketle bu sanat dalının, Mısır, Anadolu, Mezopotamya ve Çin başta olmak üzere eski uygarlıkların pek çoğunda bilindiği anlaşılmaktadır. Söz konusu örneklerin daha çok ahşap üzerine sedef, fildişi, volkan camı (opsidiyen) ve altın, gümüş üzerine lapis lazuli, turkuaz, akik gibi kıymetli taş kakmalı oldukları görülmektedir. ${ }^{11}$ Ayrıca, el sanatlarında, maden üzerine değerli taş ya da farklı bir maden, ahşap üzerine sedef, bağa, fildişi, kemik gibi farklı malzemenin kakıldı̆̆ örneklerle de yoğun bir şekilde karşılaşılmaktadır. Nitekim Selçuklular döneminde maden sanatında çok önemli bir yenilik olarak, tunç veya madeni kaplar üzerine gümüş kakma tekniği de geliştirilmiştir. ${ }^{12}$

Kakma tekniği, ilk uygulamalarda daha çok el sanatlarında tercih edilirken zaman içerisinde mimaride de kullanılmıştır. Bu kullanım,

11 Bozkurt, "Kakmacilık", 216.

12 Oktay Aslanapa, Türk Sanatı, bs. (İstanbul: Remzi Kitabevi 1993), 333. 
mimaride tekdüzelikten kaçınma ve görsel zenginliğe önem verme kaygısının bir sonucu şeklinde de yorumlanmaktadır. ${ }^{13}$

Suriye Zengî Sanatı etkileri olarak yorumlanan renkli taş kakma tekniğgi, Artuklu döneminde sadece mimari yapılarda değil etnografik maden eserlerinde ve sikkelerde de karşımıza çıkmaktadır. ${ }^{14}$ Eser skalası oldukça geniş olan Artuklu ustalarının yaptıkları eserlerde çeşitli teknikleri denedikleri, bazı yapıtlarda birkaç süsleme tekniğini bir arada kullandıkları da görülmektedir.

Kakma tekniği, Osmanlı Sanatında da cilt örneklerinden maden sanatına ve mimarideki süslemelere kadar geniş bir alanda farklı taş ve malzemelerle uygulanmıştır. Kakmacılığa büyük önem veren Osmanlılar, bu sanat dalını Tiflis, Suriye ve Mısır' dan getirdikleri ustalarla geliştirmişlerdir. ${ }^{15}$ Mimaride ise özellikle taş veya tuğla malzeme üzerine çini kakma tekniği, pencere sövelerinde, minarelerde, mihrabiyelerde vb. mimari elemanların belli noktalarında sıklıkla kullanılmıştır.

\section{Kakma Tekniğinin Uygulama Alanları: Mardin Dini Yapılarından Örnekler}

Çalışmanın bu bölümünde, incelediğimiz eserlerin kakma teknikli süsleme detaylarını vermeye çalışacağız. Eserlerin kısaca tarihi ve mimari özellikleri verildikten sonra süsleme kompozisyonları ayrıntılı bir şekilde açıklanacaktır.

\section{A. Latifiye Camii}

Latifiye Camii, Latifiye Mahallesi 152. Sokak No: 2 adresinde ve 509 Ada 14 numaralı parsel ile kayıtlıdır. Doğu-batı doğrultusunda uzanır vaziyette konumlanan caminin kitabesinde ${ }^{16}$, Melik es-Salih ve Melik elMuzaffer'in Hizmetkârı Abdüllatif bin Abdullah, tarafından h.772 /m.1371 yılında yaptırıldığı ifade edilmektedir. ${ }^{17}$ Kitabeden, bânînin Artuklu Sultanlarına hizmet eden Abdüllatif olduğu öğrenilmektedir. Latifiye Camii, birçok onarım geçirmiş ve 1968 yılındaki onarımlarda avlu tamamen bozulmuş, ana mekânın avluya bakan kuzey cephesi bir takım eklemelerle

13 Nevin Ayduslu, "Selçuklu Ve Beylikler Döneminde Kakma Çiniler Ve Günümüz Sanatından Bir Kaç Örnek", Güzel Sanatlar Enstitüsü Dergisi, 29, (2012):18.

14 Engin Beksaç, “Eyyubiler (Sanat)” ,Türkiye Diyanet Vakfi İslam Ansiklopedisi, XII, (1995): 32; Turan, Artuklu Dönemi Tarihi Yapılarındaki Figürlü Süslemeler Ve Orta Asya Kültürünün Etkileri, 69.

15 Bozkurt, "Kakmacilık", 217.

16 Yapıda yer alan kitabeler hakkında detaylı bilgi için bkz., Karaçam, Artuklu Kitabeler (1102-1409), 190-200.

17 Altun, Mardinde'ki Türk Devri Mimarisi, 43; Gabriel, Şarki Türkiye'de Arkeolojik Geziler, 26-27. 
özgünlüğünü yitirmiştir. ${ }^{18}$ Harim mekânı enine gelişme gösteren küfe planlı olup kuzeyinde revaklı bir avlusu bulunmaktadır. Caminin günümüzdeki minaresi, 1845 yılında Musul Valisi Gürcü Mehmet Paşa tarafından yaptırılmıştır. ${ }^{19}$

Latifiye Camii'nde süslemenin yoğun kullanıldığı ve iki renkli taş süslemenin kakma tekniği ile uygulandığı bölümü taç kapısıdır (Fotoğraf 3 , 4). Kesme taştan yapılan Latifiye Camii'nin taç kapısı, Mardin yapıları içinde en iyi korunmuş taç kapı olarak karşımıza çıkmaktadır. Dikdörtgen bir çerçeve içine alınan taç kapı; dışa taşkın, caminin ana mekânı boyunca yükselen bir sıra profilli silme, bir sıra mukarnaslı silme ile sonlanmaktadır. Derin bir niş şeklinde kurgulanan taç kapıyı, mukarnas başlıklı iki sütuncenin üzerinde iki renkle (sarı kalker taşı ve açık mavi mermer) oluşturulmuş üç dilimli kemer ve mukarnas kavsarası örtmektedir (Fotoğraf 4). ${ }^{20}$ Avluya geçiş sağlayan dikdörtgen formlu kapı açıklığının üstünde iki adet geometrik desenli bordür bulunmaktadır (Fotoğraf 5). Kapıyı üç taraftan çevreleyen birinci bordür iki renkli olup silmelerle köşelerde iç içe geçirilmiş, sekiz kollu yıldızlardan oluşmaktadır. Yan taraflar ise daha uzun sekiz kollu yıldızlarla benzer çokgenlerin iç içe geçirilmesiyle oluşturulmuş kabarık bir bezemeye sahiptir. İkinci bordür, bu bezemenin üst kısmında bir şerit halinde sadece ön yüzeydedir. İkinci bordürün süslemesi iç içe geçirilmiş farklı büyüklüklerdeki sekiz kollu yıldızlarla oluşturulmuş bir kompozisyona sahip olup kakma tekniğinin uygulandığı bölümdür. Yüzeysel kabartmalara sahip taş yüzeyindeki yıldızların ve aralarında kalan geometrik şekillerin içleri siyah renkli başka taşlarla kakma tekniğinde doldurulmuştur. İki renkli taş ile kompoze edilen bu yüzeydeki süsleme bordüründe yıldız motifinin ortasına konumlandırılmış aynı boyutlarda üç adet kabara dikkati çekmektedir (Fotoğraf 6, Çizim 1). İç içe geçmiş kıvrımdallar ile süslenen kabaraların ortasında ise gülbezek motifi bulunmaktadır.

\footnotetext{
Yapının detaylı mimari özellikleri için bkz., Altun, Anadolu'da Artuklu Devri Türk Mimarisi'nin Gelişmesi, 100; Altun, Mardinde'ki Türk Devri Mimarisi, 45.

19 Altun, Mardin'deki Türk Devri Mimarisi, 43; Yuvalı, “Artukoğulları Döneminde Mardin'deki Maddi Kültür Unsurları", 34 .

20 Üç dilimli kemer, Mardin ve çevresindeki yapılarda sıkça kullanılan, kuşatma kemerleri arasında özel bir yer teşkil eder, bkz., Ünal, Osmanlı Öncesi Anadolu-Türk Mimarisinde Taç Kapılar, 41.
} 


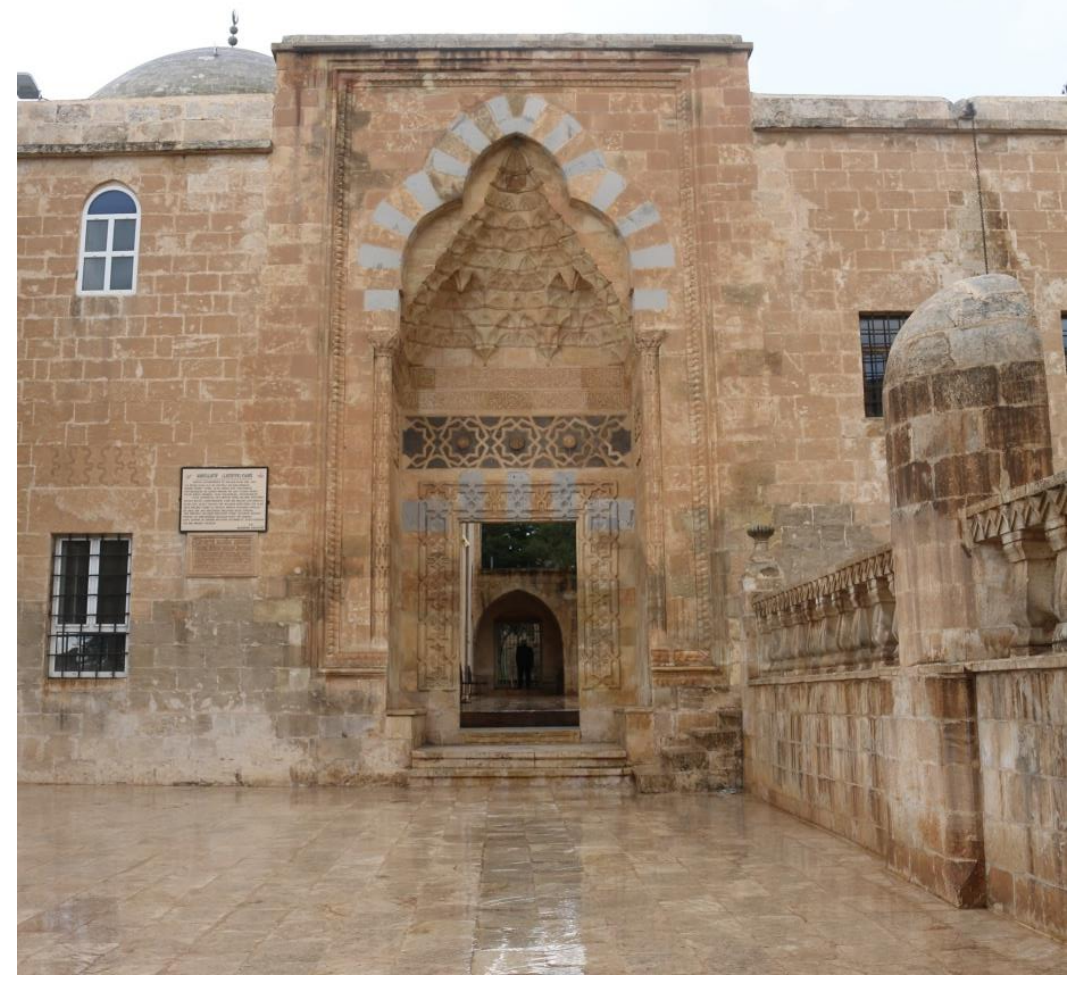

Fotoğraf 3. Latifiye Camii 


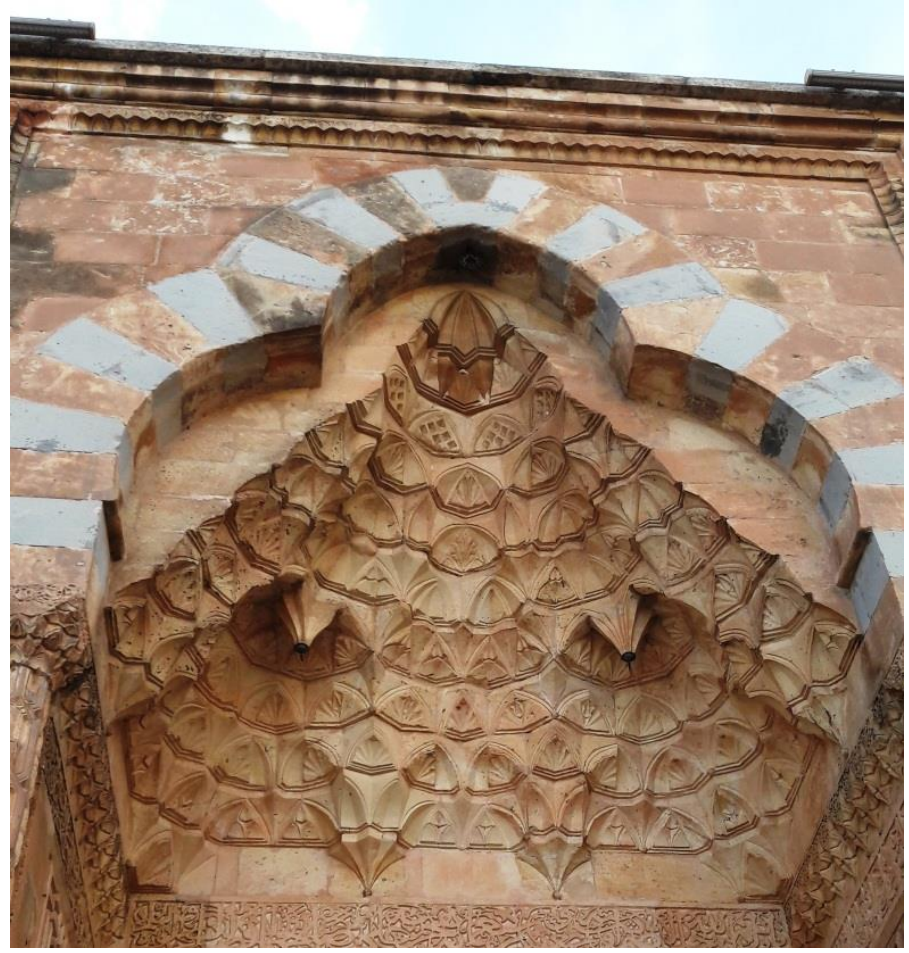

Fotoğraf 4. Latifiye Camii Taç Kapı Kavsarası 


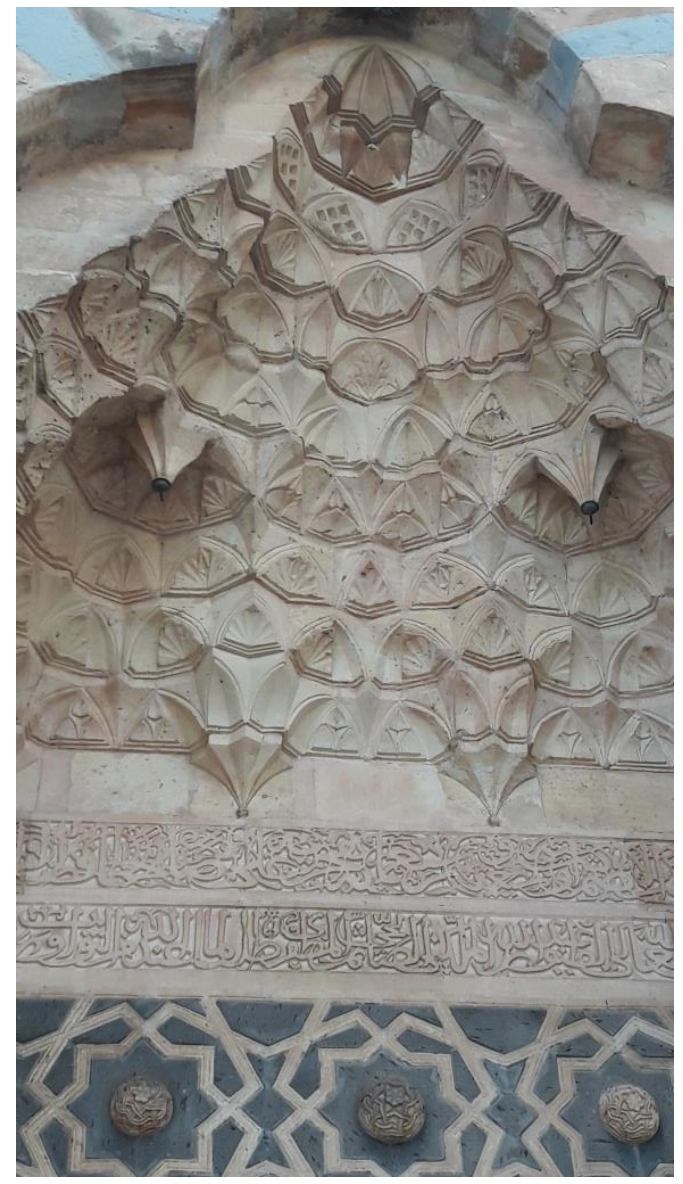

Fotoğraf 5. Latifiye Camii Taç Kapı Detayı

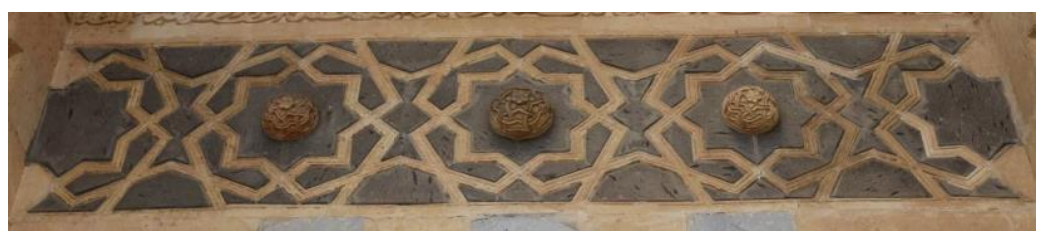

Fotoğraf 6. Latifiye Camii Taç Kapısındaki Kakma Tekniği Süsleme Detay1 


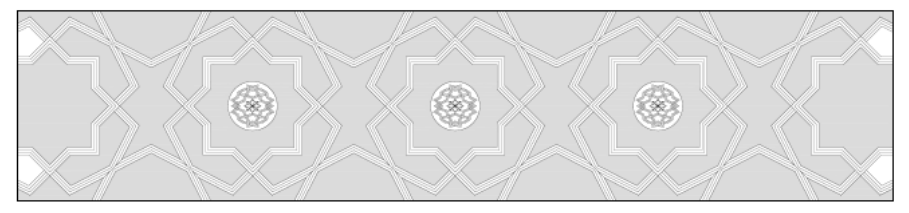

Çizim 1. Latifiye Camii Taç kapıdaki Kakma Tekniği Süsleme Detayı

\section{B. Zinciriye Medresesi}

Medrese Mahallesinin kuzeyinde bulunan Zinciriye Medresesi'nin ${ }^{21}$ taç kapı nişinin duvar yüzeyindeki yazı kuşağından ${ }^{22}$, Sultan Melik Zâhir İsâ tarafından h.787/m.1385 ${ }^{23}$ yılında yaptırıldığı öğrenilmektedir. ${ }^{24}$ Geniş bir alanı kaplayan medrese, mescid, türbe ve ek yapılardan meydana gelmiştir.

Yapının, kuzey cephesi sağır, güney cephesi görünür bir şekilde araziye doğu-batı doğrultusunda uzanır vaziyette yerleştirilmiştir. Zinciriye Medresesi ana işlevleri mescid ve medrese olan iki kütlenin birleşmesiyle tasarlanmış açık avlulu medrese planına sahiptir. Medresenin batı ucunda türbe, doğusunda ise mescid ile anıtsal nitelikte taç kapılı girişi yer alır (Fotoğraf 7). ${ }^{25}$

21 Bulduk, Mardin Tarihi, 89; Orhan Cezmi Tuncer, "Artuklu Yapıları (yaptıran, yürüten ve yapanlar)”, I. Uluslararası Artuklu Sempozyumu Bildirileri, 25-26-27 Ekim 2007 Mardin, ed. İbrahim Özçoşar, Mardin Valiliği, (Mardin 2008), II, 152; Yuvalı, “Artukoğulları Döneminde Mardin' deki Maddi Kültür Unsurları”, 34; Artuk, "Mardin Zinciriye Medresesi ve Bânisi", 191-194.

22 Yapıda yer alan kitabeler hakkında detaylı bilgi için bkz., Karaçam, Artuklu Kitabeler (1102-1409), 202-211.

23 Yuvalı, "Artukoğulları Döneminde Mardin'deki Maddi Kültür Unsurları", 32; Gabriel, Şarki Türkiye'de Arkeolojik Geziler, 29.

24 Mustafa Diğler, Seçkin Aydın, "Mardin'de Artuklu Dönemine Ait Taş İşçiliğinde Kullanılan Motiflerin Plastik Öğeleri", I. Uluslararası Artuklu Sempozyumu Bildirileri, 25-26-27 Ekim 2007 Mardin, ed. İbrahim Özçoşar, Mardin Valiliği, (Mardin 2008), II, 369; Sözen, Anadolu Medreseleri I, 187; Orhan Cezmi Tuncer, Diyarbakır Camileri. bs. (Ankara: Diyarbakır Belediyesi Yayınları,1996),58; Çağlayan, Tanyeli, "Mardin Zinciriye (Sultan İsa) Medresesi ve Osmanlıdan Günümüze Medresedeki Restorasyon Müdahaleleri”, 89.

25 Yapının mimari özellikleri hakkında detaylı bilgi için bkz., Çağlayan, "Bir Mimari Karşılaştırma: Mardin Zinciriye ve Kasımiye Medreseleri",149. 


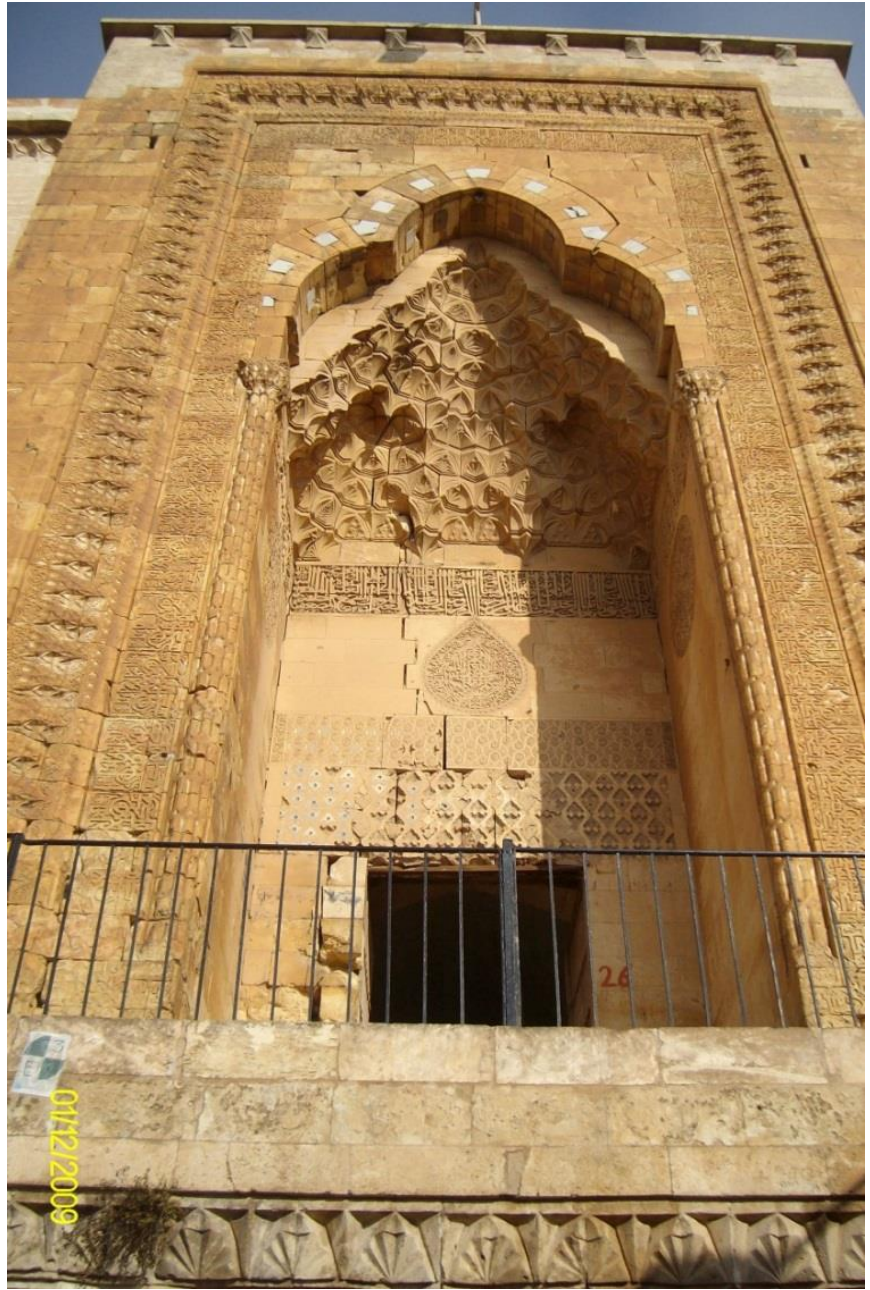

Fotoğraf 7. Zinciriye Medresesi Taç Kapısı

Açık renkli, sarımsı kesme kalker taştan inşa edilen binanın bezeme kompozisyonlarının büyük çoğunluğunda renkli taş ve mermer malzeme kakma tekniği ile kullanılmıştır.

Medresede süsleme programının yoğunlaştığı taç kapı, kubbeler, kap1 ve mihrap kavsaraları dikkat çekmektedir. En yoğun süslemenin görüldüğü taç kapı; dışta iki sıra mukarnas kademesin, içte bir taraftan rumilerden diğer tarafta palmetlerden oluşan bordürlere sahiptir. "Tevekkel alâ'llah" tamlamasının tekrar edildiği örgülü kûfi yazı şeridi iki yanda geometrik örgü 
motifleri ile bezenmiş iki sütünce ile son bulmaktadır. ${ }^{26}$ Taç kapıda hem kakma tekniği hem de oyma tekniğinin kullanıldığı görülmektedir.

Medresenin taç kapısı, mescid mihrabı ile giriş açıklığının harime bakan cephesinin etrafında ve türbenin bulunduğu bölümdeki mescidin mihrabında iç mekâna bakan giriş açıklığının üzerinde ve kemerinde kakma teknikli süslemeler uygulanmıştır.

Taç kapının dilimli kemer taşlarında ve kemer karnında fildişi renkli mermer malzeme kübik taşlar halinde kakma olarak yüzeye aplike edilmiştir. Giriş açıklığının üzerinde iki süsleme bordüründe de aynı teknik kullanılmıştır (Fotoğraf 8). İlk bordürde taşın yüzeyinde biri aşağı biri yukarı bakacak şekilde içi oyulmuş palmetler yan yana dizilmiştir. Palmetlerin oyulan içleri yine fildişi renkli mermer malzeme ile kakma tekniğinde tamamlanmıştır (Fotoğraf 9). Üstte yer alan ikinci bordürde ise kıvrık dalların bir alttan bir üstten geçirilmiş örgü sisteminin aralarında kalan geometrik şekillerden oluşur. Altıgen formlu bu bölümlerde oyma tekniği ile tek kelimelik Arapça celi sülüs hatla yazılmış 'Esmâ-yi Hüsna' (Allah'ın isimleri) yer alır. ${ }^{27}$ İç içe geçmiş kıvrım dalların aralarında oluşan stilize palmet motifleri de yine kakma tekniğinde fildişi renkli malzeme ile tamamlanır (Fotoğraf 10).

\footnotetext{
Tuncer, "Artuklu Yapıları (yaptıran, yürüten ve yapanlar)", 164; Ünal, Osmanlı Öncesi Anadolu-Türk Mimarisinde Taç Kapılar, 57, şek.165.

27 Çaça, Mardin'de Artuklu Dönemine Ait Bir Medrese: Zinciriye (Sultan İsa) Medresesi,181.
} 


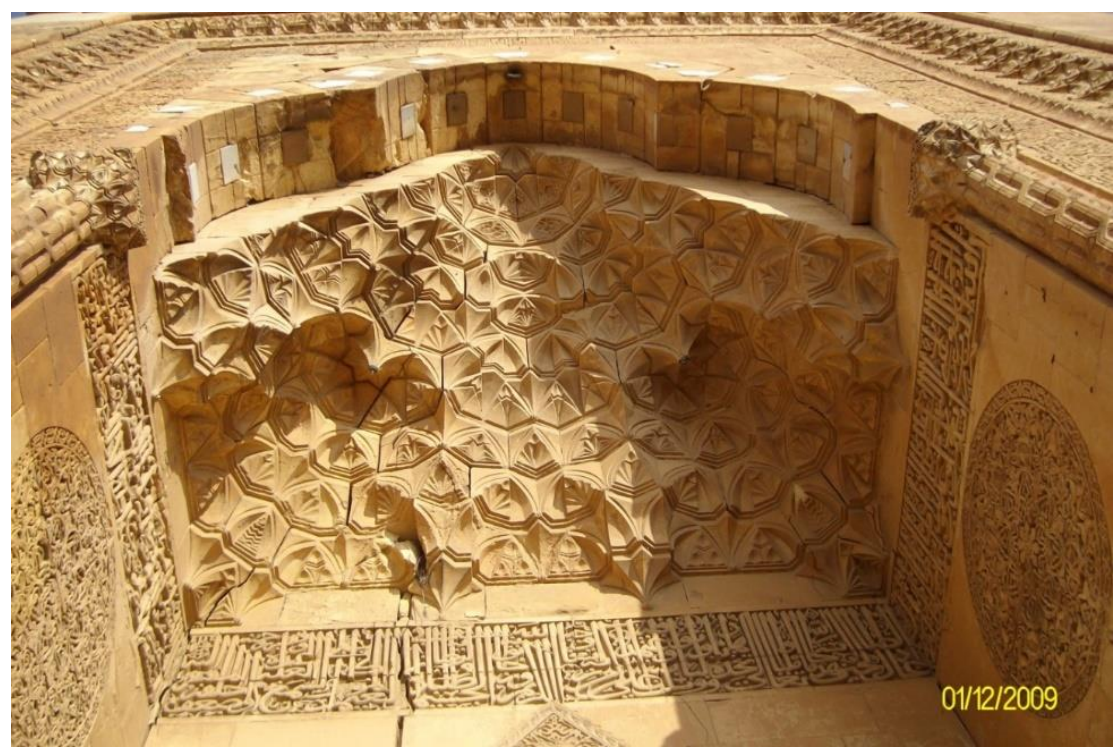

Fotoğraf 8. Zinciriye Medresesi Taç Kapısı Mukarnas Kavsarası

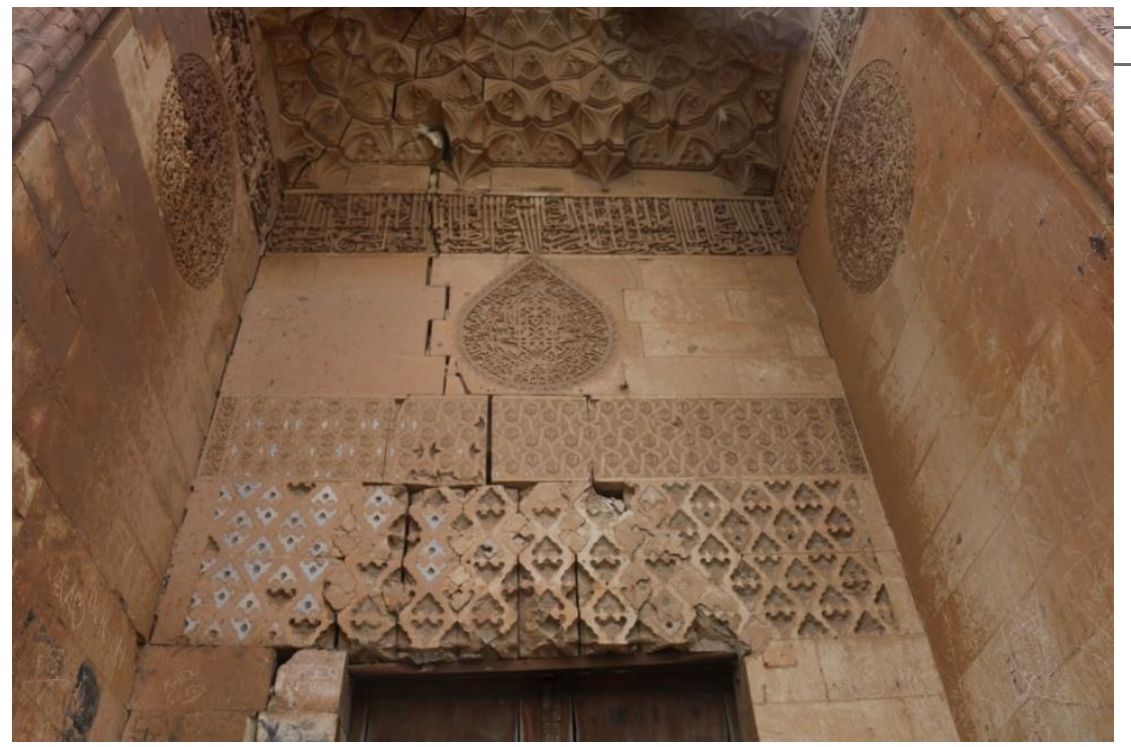

Fotoğraf 9. Zinciriye Medresesi Taç Kapısı Kakma Teknikli Süsleme Bordürü 


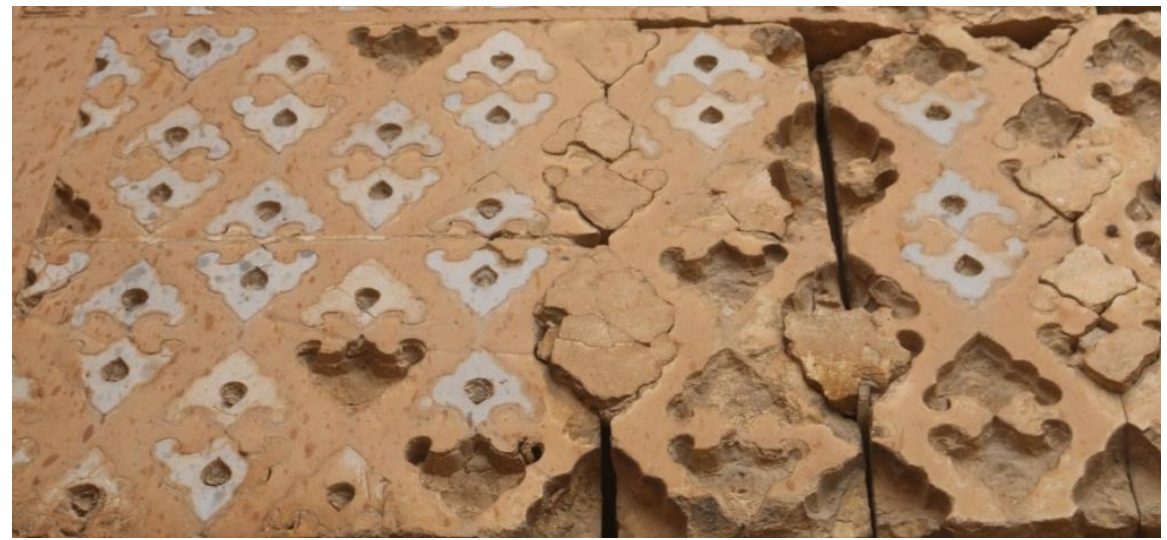

Fotoğraf 10. Zinciriye Medresesi Taç Kapsı Kakma Teknikli Süsleme Bordüründen Detay

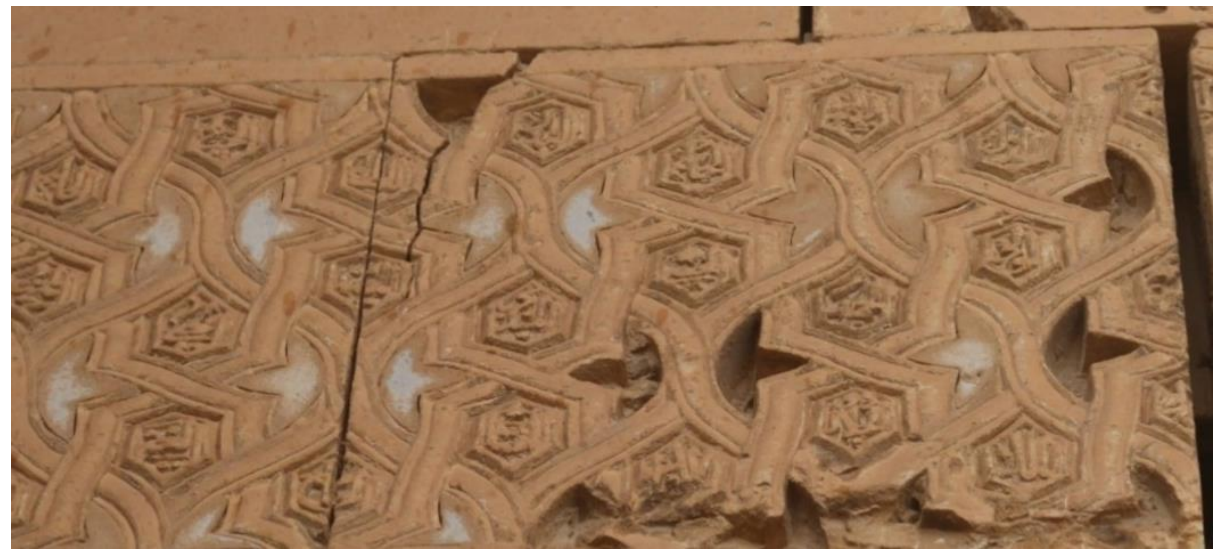

Fotoğraf 11. Zinciriye Medresesi Taç Kapısı Kakma Teknikli Süsleme Bordüründen Detay

Medresenin süsleme programında büyük öneme sahip bir diğer ünite mescidin mihrap nişidir. Mescid mihrabı yarım daire formlu nişe sahiptir. Nişi örten iç içe yerleştirilmiş iki sivri kemer ile mihrabın köşeliklerinde yüzeysel oyma tekniğinde rumi ve palmetlerden oluşan bitkisel süslemeler yer alır. Mihrap nişini ve bu süslemeleri de içine alacak şekilde dikdörtgen bir çerçeve kompozisyonu tamamlar (Fotoğraf 11). Süsleme bordürü, biri aşağ1 biri yukarı bakar vaziyette yan yana yerleştirilen palmet dizilerinden oluşur. Palmetlerden yukarıya bakar durumda olanların içleri oyularak kakma tekniği ile duman renkli taşlarla tamamlanır (Fotoğraf 12,13, Çizim 2). 


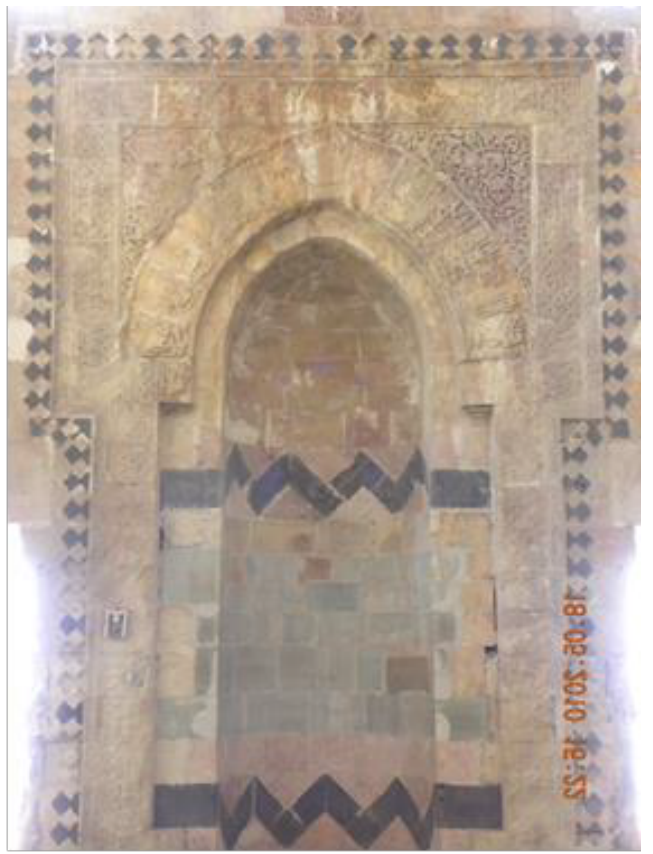

Fotoğraf 12. Zinciriye Medresesi Mescid Mihrabı

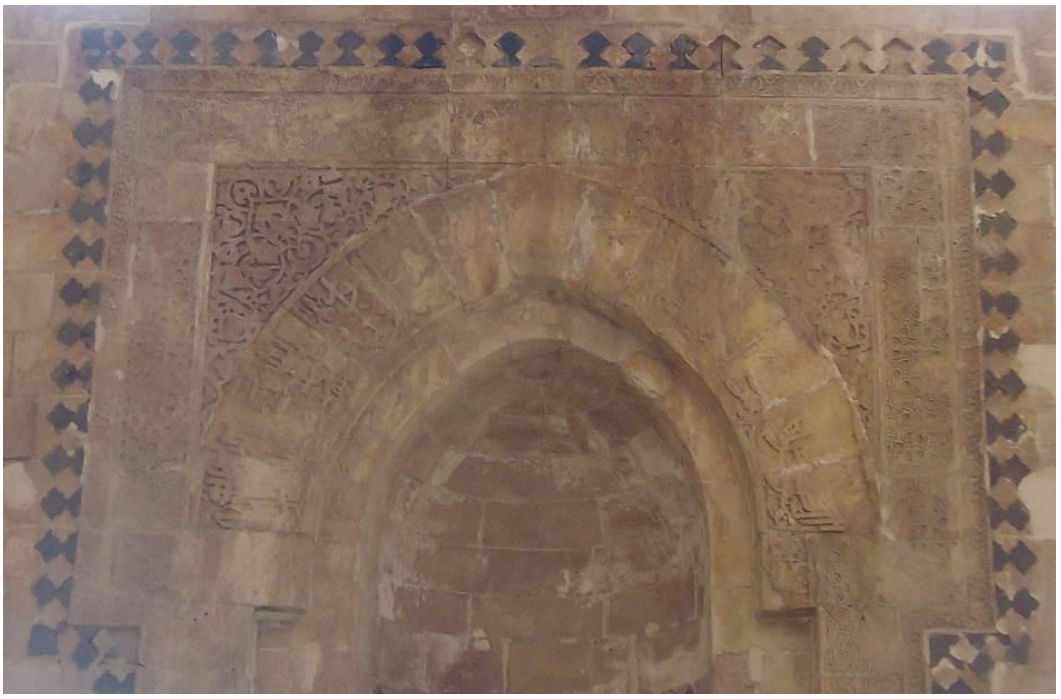

Fotoğraf 13. Zinciriye Medresesi Mescid Mihrabı Kakma Teknikli Süsleme Bordürü 


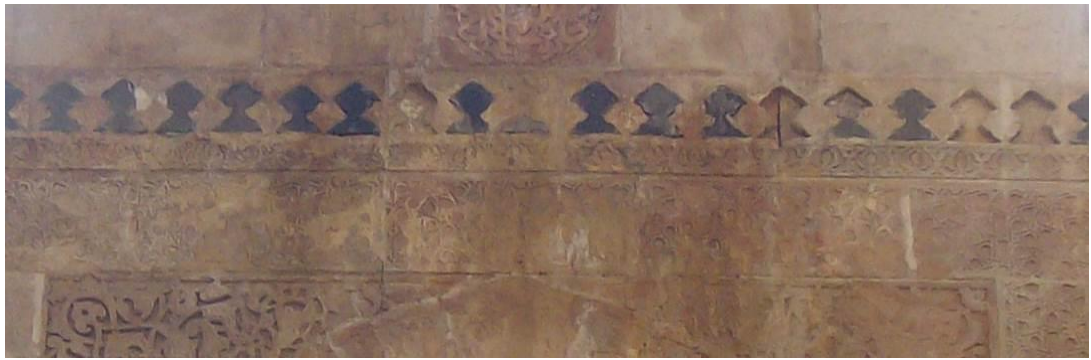

Fotoğraf 14. Zinciriye Medresesi Mescid Mihrabı Kakma Teknikli Süsleme Bordüründen Detay

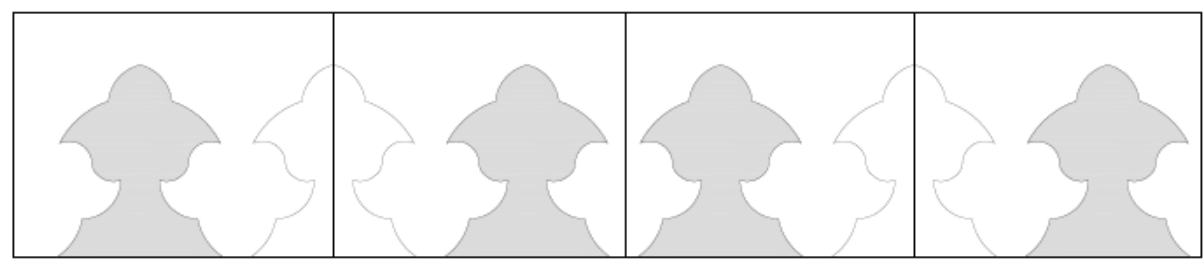

Çizim 2. Zinciriye Medresesi Mescid Mihrabı Kakma Teknikli Süsleme Bordüründen Detay

Mescid mekânına giriş sağlayan açıklığın, iç mekâna bakan yüzeyinde de kakma tekniği ile uygulanan süslemeler mevcuttur. Mihrap ile aynı aksta yer alan ve üstü mukarnaslı bir kavsara ile taçlandırılmış giriş kemerinde de mihrapta görülen bordür bezemeleri ile aynı özelliklere sahip palmet kuşağı yer alır. Süsleme kuşağında biri aşağı diğeri yukarı bakan palmet dizileri, sıralı bir biçimde kompozisyon oluşturur (Fotoğraf 14). Yukarı bakan palmetlerin içi boşaltıldıktan sonra ikinci bir işlem olarak siyah renklarla kakma tekniği ile yüzey bezenmiştir (Fotoğraf 15). Aynı özelliklere sahip mescid mihrabı ile bu süsleme kuşağındaki siyah taşların yer yer düşmüş olması bu tekniğin uygulaması hakkında fikir vermektedir (Fotoğraf 16). 


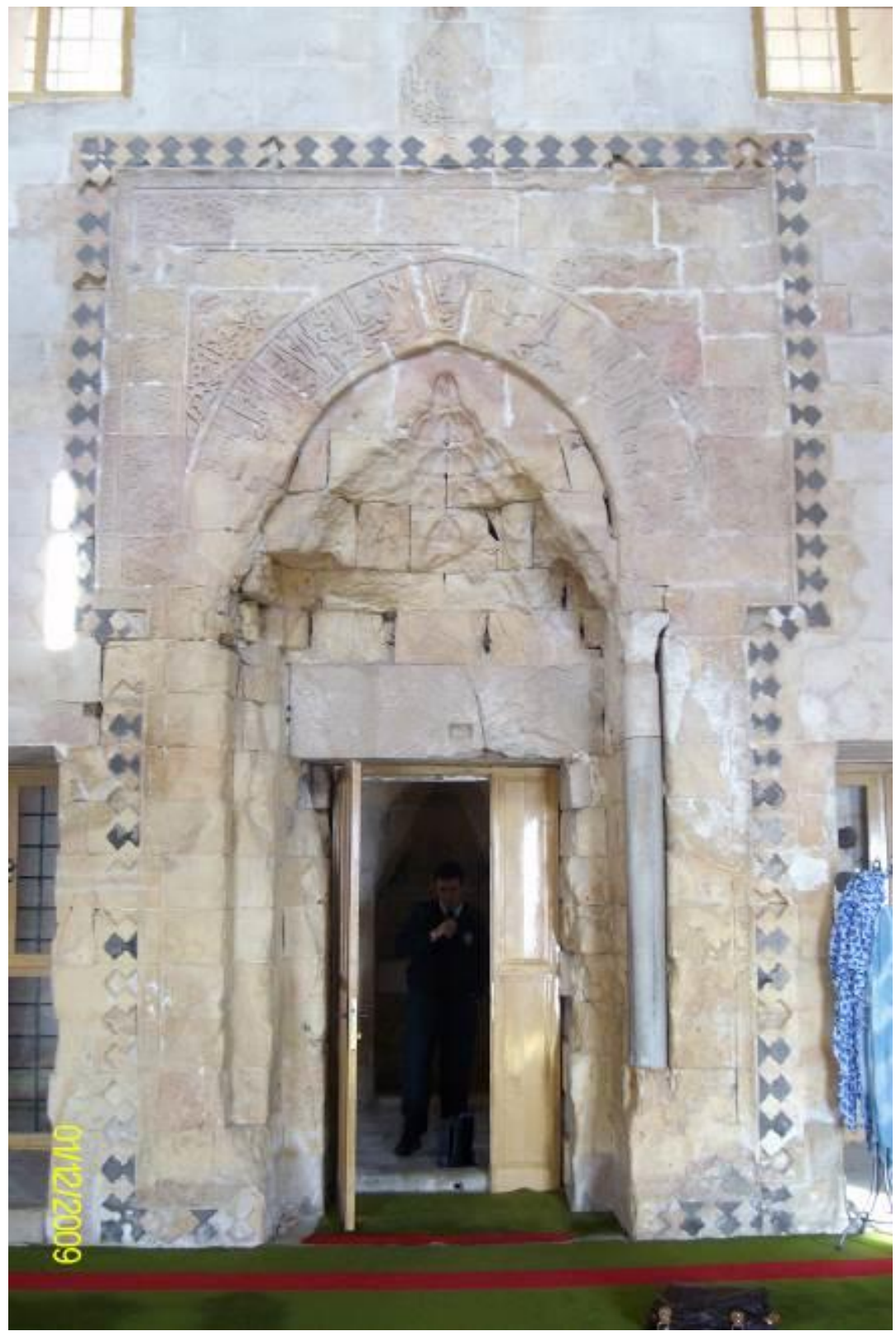

Fotoğraf 15. Zinciriye Medresesi Mescid Giriş Kapısı 


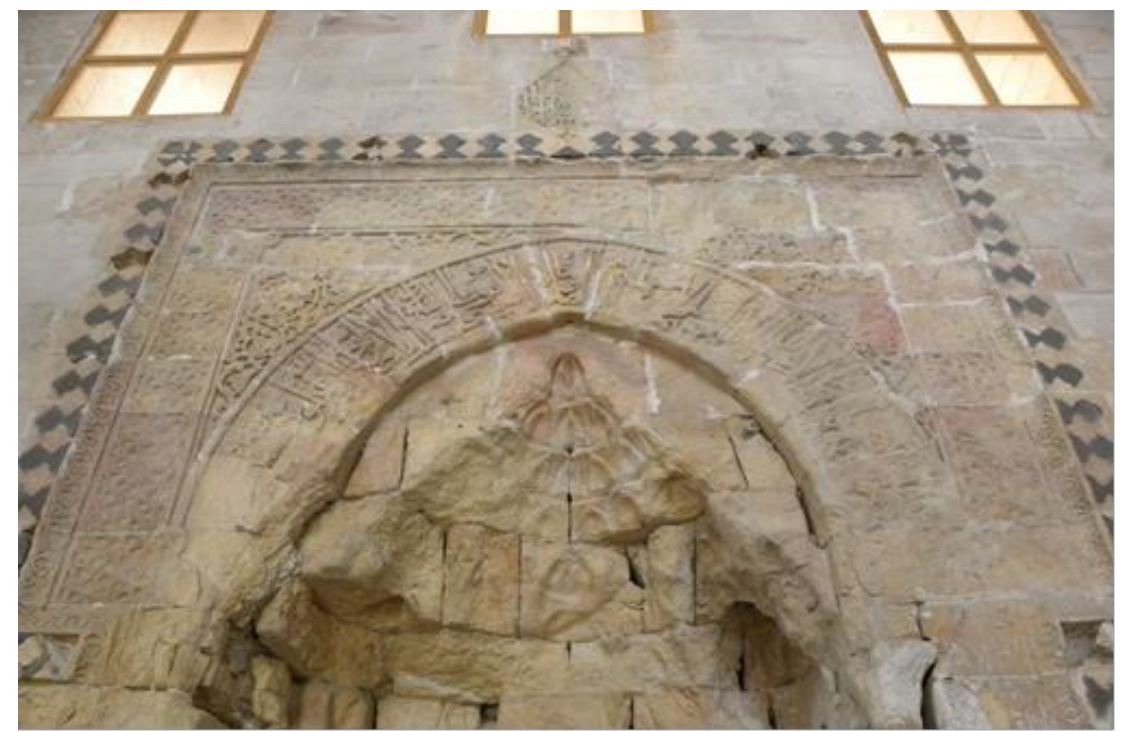

Fotoğraf 16. Zinciriye Medresesi Mescid Kapısı Kavsarası ve Süslemeleri

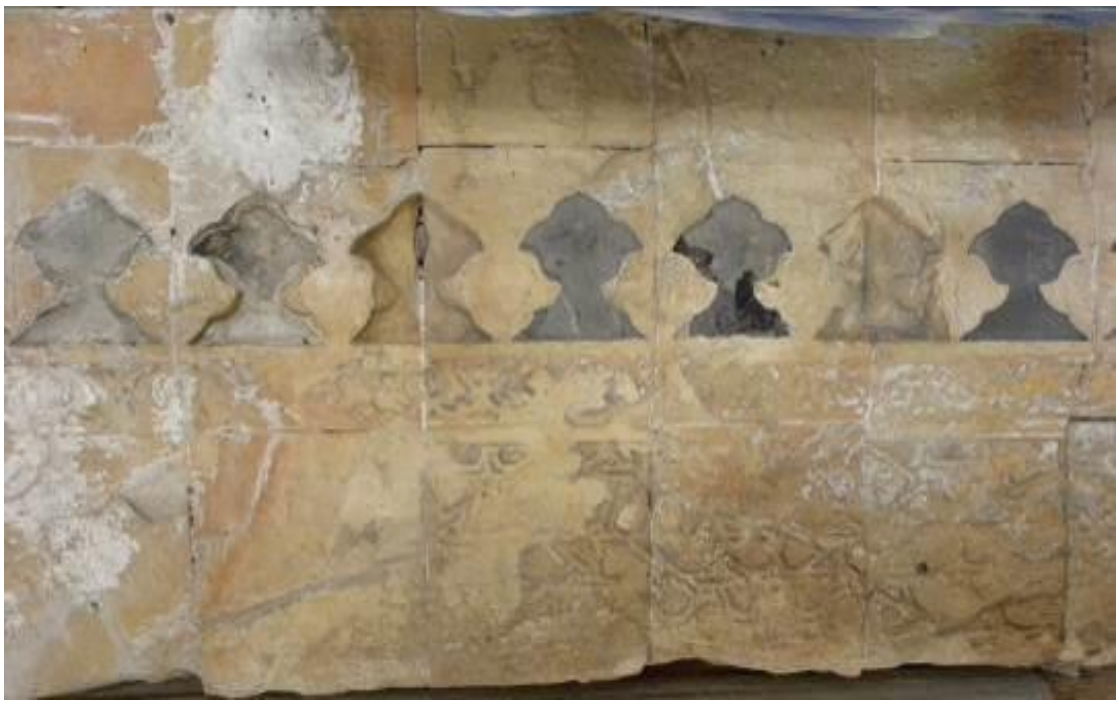

Fotoğraf 17. Zinciriye Medresesi Mescid Kapısı Kakma Teknikli Süslemelerden Detay

Kakma teknikli süslemelerin bulunduğu bir diğer bölüm ise türbe bölümündeki mescid mekânıdır. Mescide giriş sağlayan açıklığın iç mekâna bakan yüzeyindeki kakma teknikli süslemelerin büyük çoğunluğu tahrip olmuştur. Buradaki lentoda bugün kakma taşlarından sadece bir tanesi 
mevcuttur (Fotoğraf 17). Bordürde kalker taşının yüzeyi biri aşağı diğeri yukarı bakar vaziyette karşılıklı palmetlerin içi boşaltılarak yuvaların içlerinin siyah (duman rengi) renkli taşlarla doldurulduğu anlaşılmaktadır (Fotoğraf 18). Yine açıklığın üzerindeki sivri kemerde kilit taşı, siyah olarak tercih edilmiştir. Kilit taşının üzerinde yer alan palmet motifinin yapraklarının içleri oyularak bu bölümlere farklı renkte bir malzemenin kakıldığı kalan izlerden okunabilmektedir. Yarım daire formlu mihrabın kavsarasında zig zag biçimleri ile aralarına oturtulmuş palmet motiflerinin içleri oyularak duman renkli taşlarla kakma tekniğinde doldurulmuştur. Mihrabın en dıştaki kemerinin kilit taşına ters oturtulmuş bir palmet motifi de kakma tekniği ile tamamlanmıştır (Fotoğraf 19).

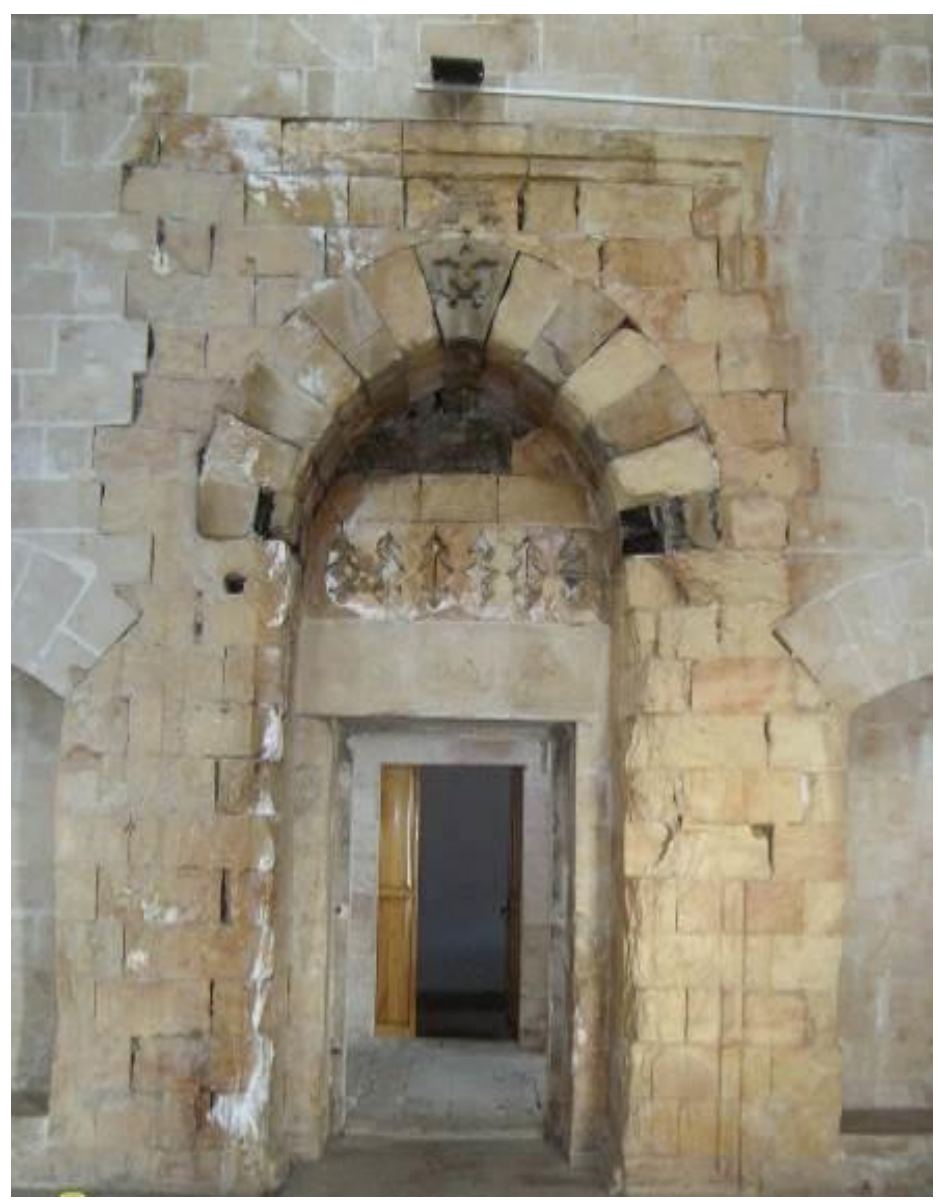

Fotoğraf 18. Zinciriye Medresesi Türbe Bölümündeki Mescid Kapısı 


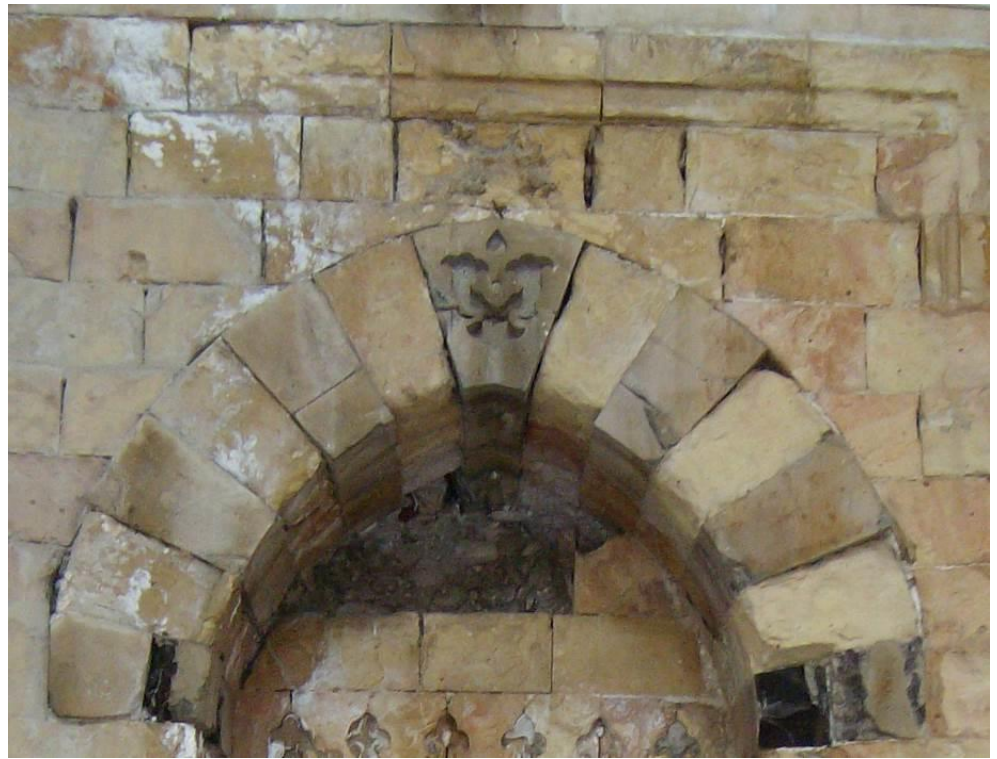

Fotoğraf 19. Zinciriye Medresesi Türbe Bölümündeki Mescid Kapısı Süsleme Detayı

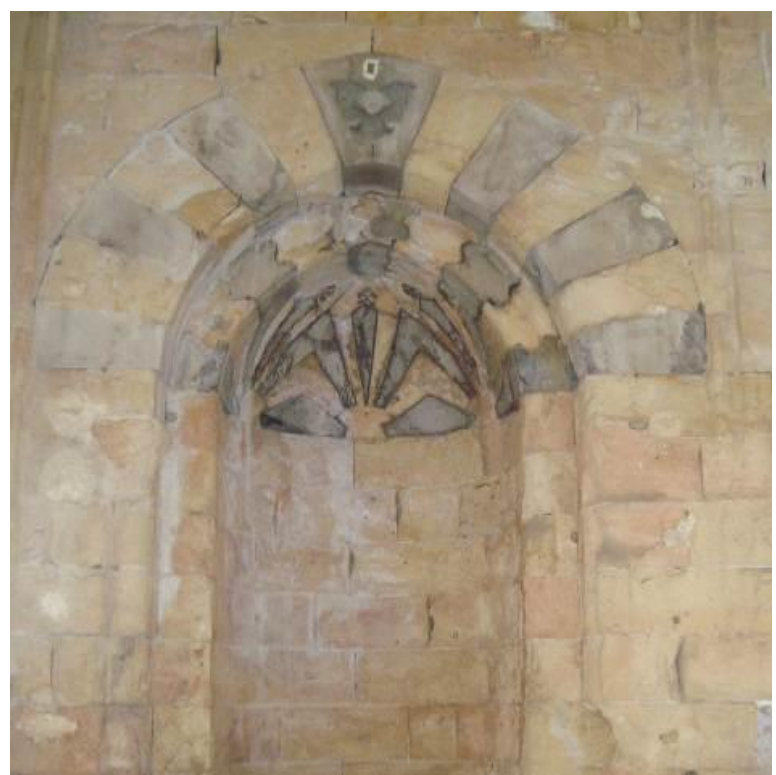

Fotoğraf 20. Zinciriye Medresesi Türbe Bölümündeki Mescid Mihrabı 


\section{Hamza-i Kebir Camii}

Mardin, Artuklu İlçesi, 1. Cadde üzerinde Savurkapı (Bab es-Sur) Mahallesinde Meydanbaşı yakınlarında yer alan cami, tapuda 158 ada, 2 parsel numarası ile kayıtlıdır. ${ }^{28}$ Eserin ilk inşa edildiğinde zaviyeyi oluşturan bir yapı olduğu bilinmektedir. ${ }^{29}$ Yapıya geçişi sağlayan kapı açıklı̆̆ının üzerindeki duvar yüzeyinde dikdörtgen formda iki parça halinde bir kitabe yer almaktadır (Fotoğraf 20). Büyük oranda tahrip olan ve bugün okunamayan kitabe daha önce İbrahim Artuk tarafından neşredilmiştir. Kitabede inşa tarihi olarak h. 842/m. 1438-39 yılı geçmektedir. ${ }^{30}$ Eser, bânîsi olan Akkoyunlu Devleti'nin hükümdarı Sultan Hamza tarafından kendisinin ölümünden önce türbe olarak inşa edilmiştir. Diyarbakır'da vefat eden Sultan'ın cenazesi, yapının da içinde bulunduğu zaviyenin avlusuna defnedildiğinden dolayı yapı da mescid olarak kullanılmıştır. ${ }^{31}$

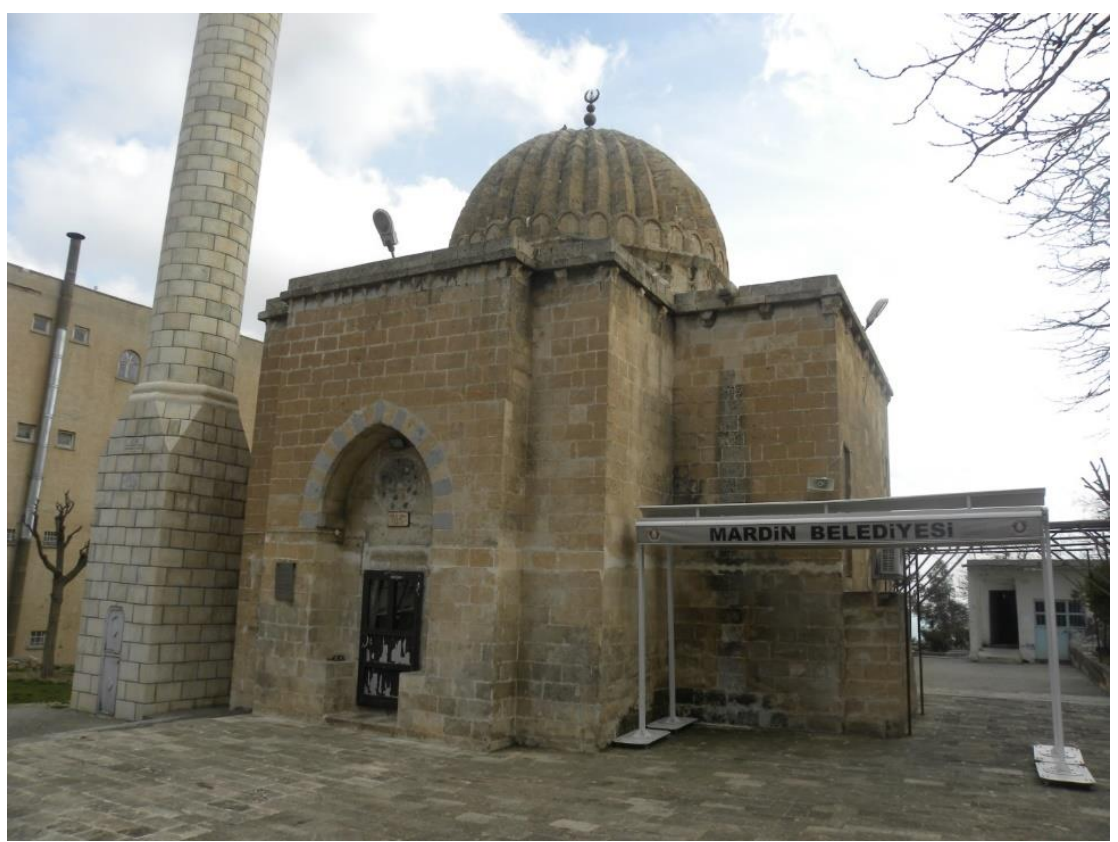

Fotoğraf 21. Hamza-i Kebir Camii Genel Görünüşü

28 Yeşilbaş, “Hamza-i Kebir Türbesi Üzerine Yeni Değerlendirmeler", 163-182.

29 Nejat Göyünç, XVI. Yüzyılda Mardin Sancă̆ı, bs. (Ankara: Türk Tarih Kurumu, 1991),120; Altun, Mardin'deki Türk Devri Mimarisi, 116; Yeşilbaş, “Hamza-i Kebir Türbesi Üzerine Yeni Değerlendirmeler",168.

30 İbrahim Artuk, Artuk İlinin Tarihi Belgesi, bs. (İstanbul: Güven Basımevi, tsz); Hamza Keleş, “Anadolu' da Akkoyunlu Kültür Mirası; Tarihi Eserler”, Türk Kültürü Ve Hacı Bektaş Veli Araştırma Dergisi, 38, (2006): 71; Nevin Soyukaya vd., Mardin Kültür Envanteri. bs. (İstanbul: Mardin Valiliği, Çekül Yayınları 2013), 132.

31 Yapı ile ilgili detaylı bilgi için bkz., Yeşilbaş, "Hamza-i Kebir Türbesi Üzerine Yeni Değerlendirmeler",168. 
Yapı, Anadolu' da türbe mimarisinden farklı bir plan şemasına sahiptir. Ortada kare bir mekân ve dört yöne uzanan kolları ile haçvari bir plan tipindedir. Haçın kollarının birleştiği ortadaki kare alan, içten düz diştan ise dilimli bir kubbe örtülüdür. Kubbeye geçişlerde tromplar kullanılmıştır. Mukarnaslarla doldurulan trompları çevreleyen sivri kemerler, siyah ve sarımsı renkli kesme taşlar ile almaşık teknikte oluşturulmuştur.

Yapıda uygulanan kakma tekniği, Mardin'de başka bir yapıda görmediğimiz, taş malzeme üzerine çini kakma örneği ile karşımıza çıkmaktadır (Fotoğraf 21). Kapı açıklı̆̆ının üst tarafındaki duvar yüzeyinde dikdörtgen formda bir kitabenin üzerinde sekizgen formda çini kakmalı bezeme panosu mevcuttur. Panoda beş kollu yıldızlar ve düzgün olmayan altıgenler ile kompozisyon oluşturulmuştur. Kompozisyonun ortasında geometrik geçmelerin meydana getirdiği sekiz kollu bir yıldız mevcuttur (Fotoğraf 22, Çizim 3). Geometrik geçmelerin aralarındaki eşkenar olmayan altıgen boşlukların içleri, lacivert ve firuze renkli sırlı çini malzeme ile kakma olarak uygulanmıştır. Panonun yüzeyindeki boşluklardan anlaşıldığı üzere çini parçalarının bir kısmı zaman içerisinde dökülmüş bir kısmının da sırları aşınmıştır. Giriş kütlesine hareketlilik kazandıran süsleme panosu büyük oranda tahrip olmuştur.

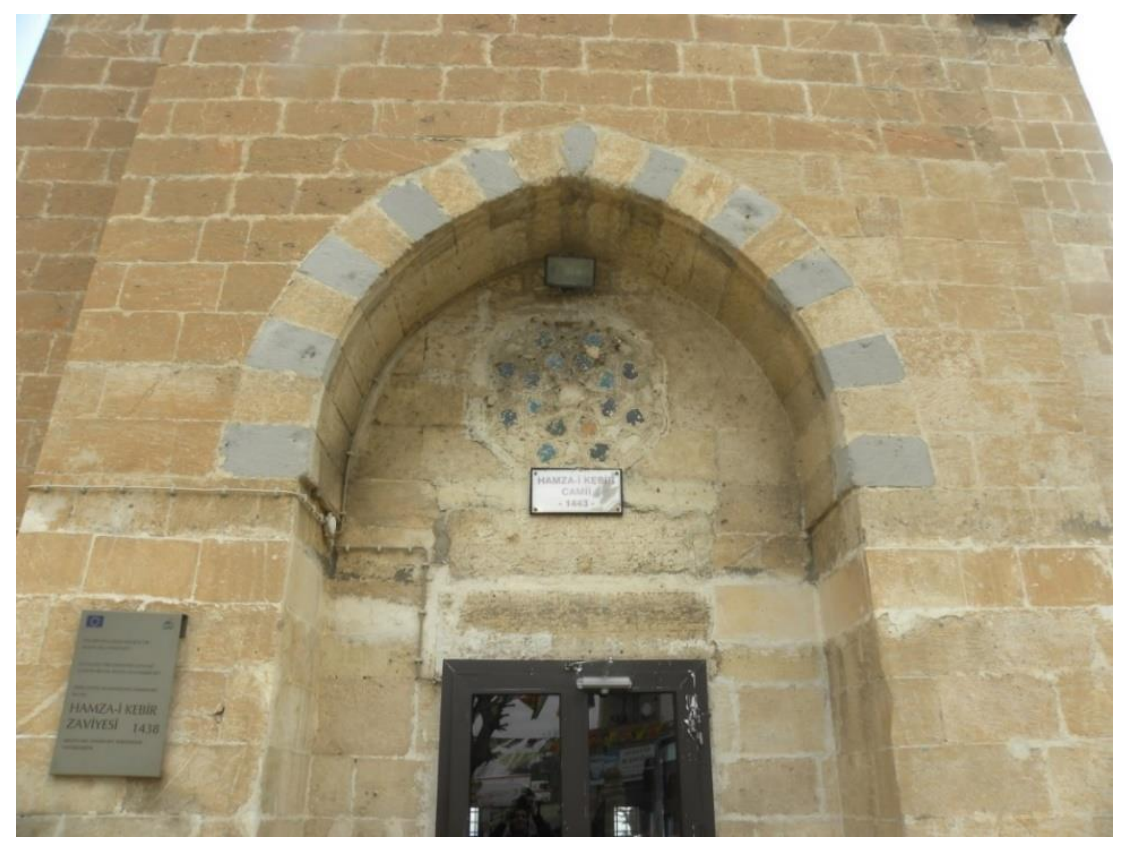

Fotoğraf 22. Hamza-i Kebir Camii Taç Kapı Sivri Kemeri 


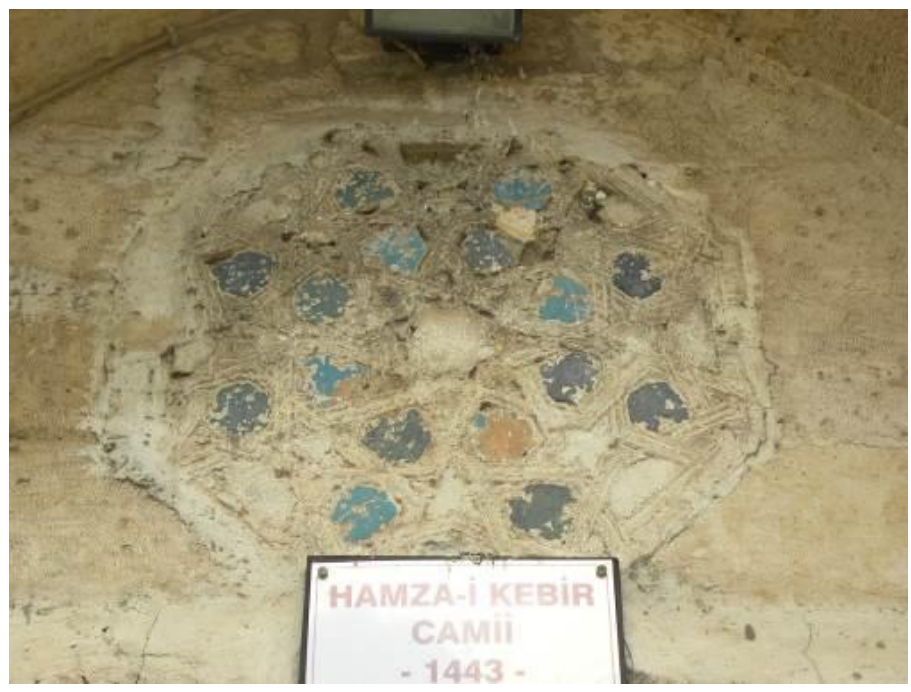

Fotoğraf 23. Hamza-i Kebir Camii Taç Kapısı Üzerindeki Süsleme Panosu

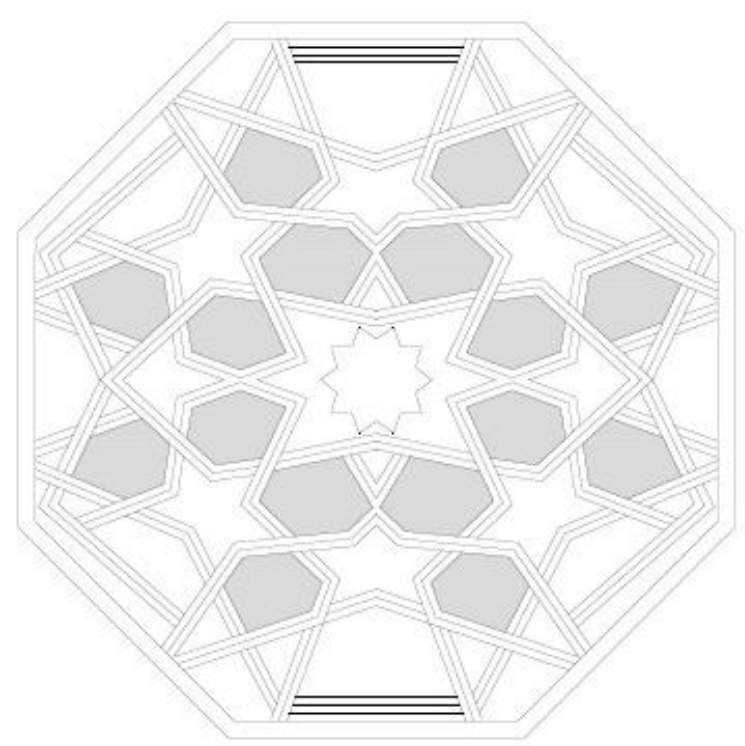

Çizim 3. Hamza-i Kebir Camii Taç Kapısı Üzerindeki Süsleme Panosu 


\section{Kasımiye Medresesi}

Medresenin yapım yılını veya yaptıranını gösteren herhangi bir kitabesi bulunmadığından, yapım tarihi hakkında kesin bir bilgiye sahip değiliz. Araştırmacılar tarafından Artuklu döneminde yapımına başlandığ $1^{32}$ Akkoyunlu hükümdarı Cihangir'in oğlu Sultan Kasım döneminde (14871502) tamamlandığ 1 kabul edilmektedir. ${ }^{33}$

Açık avlulu plan şemasına sahip Sultan Kasım Medresesi, mescid ve medrese kütlelerinin birleşmesiyle Anadolu medreselerinde karşılaştığımız planlardan farklı bir şemada tasarlanmıştır. Yapı, araziye doğu-batı doğrultusunda uzanır vaziyette konumlanmıştır. Kütlenin batı ucunda cami, doğuda ise medrese ve her iki birimin arasında da taç kapılı giriş yer almaktadır (Fotoğraf 24). ${ }^{34}$ Medresenin güney cephesi, birimlerin yerleştirilmesi bakımından kendi içinde simetrik iken, genel kurgusu asimetriktir. ${ }^{35}$

Kasımiye Medresesi'nde açık renkli, sarımsı kalker taşı; duvar, ayak, kemer, lento, geçiş öğesi ve örtü gibi yapı elemanlarından kubbelerin kaplama malzemesine dek uzanan tüm yapı ve bezeme elemanlarının biçimlenmesini sağlayan malzemedir. Kalker taşı ile birlikte, bezeme programında değişik renkte taş ve mermer malzeme de kakma tekniğinde kullanılmıştır. Medresenin taç kapısında, mescidin mihrap nişinin çevresinde ve avluda yer alan eyvan bölümlerinde kakma tekniğinde işlenmiş süslemeler bulunmaktadır.

Kasımiye Medresesi'nin taç kapısının lentolu giriş açıklığı üzerinde, kakma taşlarının büyük çoğunluğu bugüne ulaşmamıştır. Ancak bu bölümde kakma tekniğinin uygulandığı bakiyelerden anlaşılabilmektedir (Fotoğraf 25). Kompozisyonda biri aşağı diğeri yukarı bakacak şekilde karşılıklı yerleştirilmiş palmet motiflerinin içleri oyularak bu noktalara siyah renkli

32 Altun, Anadolu'da Artuklu Devri Türk Mimarisinin Gelişmesi, 277; Gabriel, Şarki Türkiye'de Arkeolojik Geziler, 36-37.

33 Yapının ismini, Sultan Kasım'dan aldığını ve söz konusu hükümdarın da 1487-1502 yılları arasında yönetimin başında bulunduğunu dayanak göstererek yapının da bu yıllar arasında inşa edilmiş olabileceği ileri sürülmektedir, bkz.,Tuncer, Diyarbakır Camileri, 58; Atalan, “Artuklu Mimarisi'nin Anıtsal Mimarisinin Korunması Üzerine Model Yaklaşımı: Kasımiye Medresesi Örneği”, 307; Berrin Alper, “Mercek Altında Bir Yapı: Sultan Kasım Medresesi”, Taşın Belleği Mardin, (İstanbul: Yapı Kredi Yayınları, 2005), 241; Ara Altun, "Mardin'de Türk Devri Anıtsal Mimarisine Genel Bakış", Taşın Belleği Mardin. bs. (İstanbul: Yapı Kredi Yayınları, 2005), 165; Metin Sözen, Anadolu'da Akkoyunlu Mimarisi, bs. (İstanbul: Türkiye Turing ve Otomobil Kurumu, 1981), 119.

34 Ünal, Osmanlı Öncesi Anadolu-Türk Mimarisinde Taç Kapılar, 66.

35 Yapının mimari özellikleri hakkında detaylı bilgi için bkz., Çağlayan, "Bir Mimari Karşılaştırma: Mardin Zinciriye ve Kasımiye Medreseleri",149; Çağlayan, "Anadolu'da Bir Akkoyunlu Kültür Mirası: Mardin Kasımiye Medresesi",1140. 
taşlar yerleştirilmiş olmalıdır (Fotoğraf 26). ${ }^{36}$ Taç kapının mukarnaslı kavsarasını çevreleyen üç dilimli kemerin karnında da beyaz renkli kübik taşların kakma tekniğinde uygulandığı düşünülmelidir.

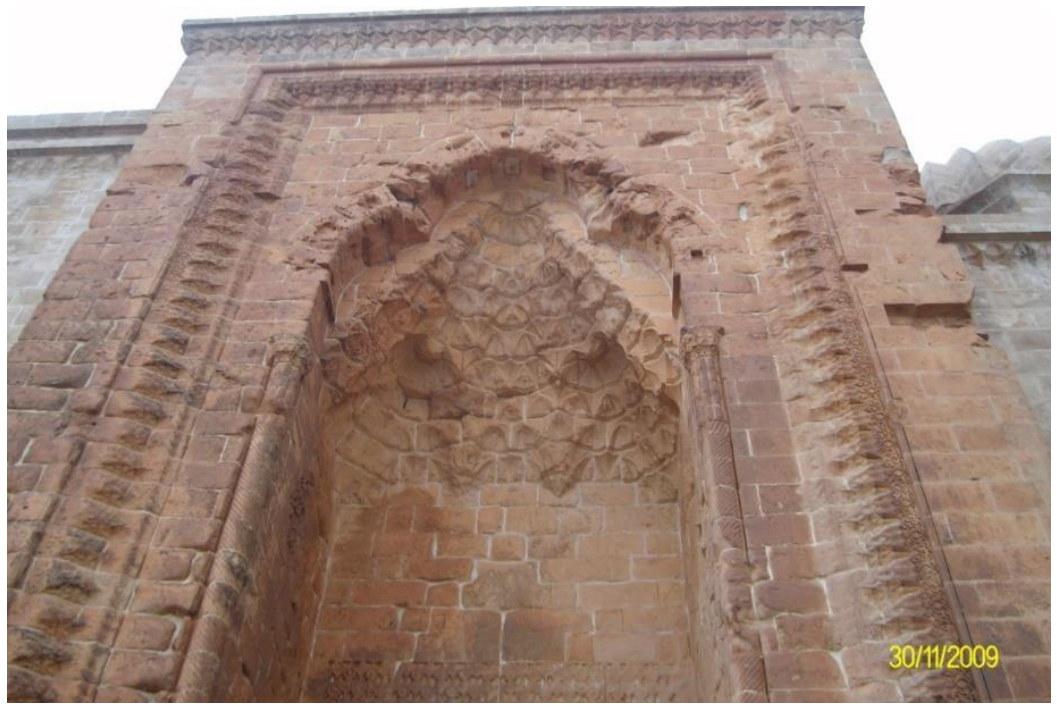

Fotoğraf 24. Kasımiye Medresesi Taç Kapısı

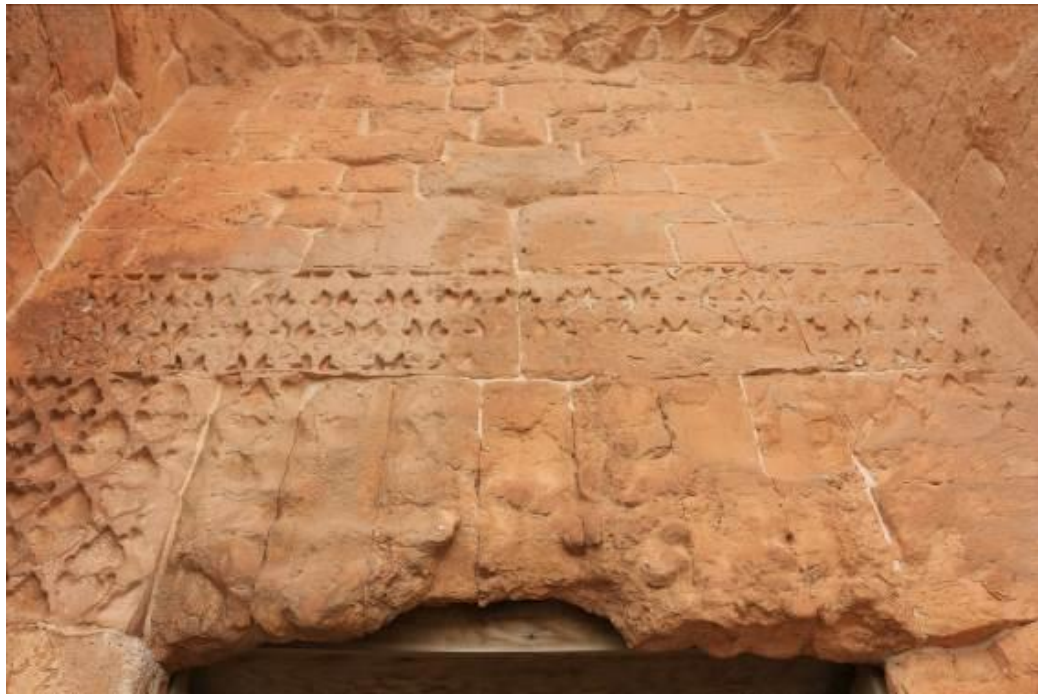

Fotoğraf 25. Kasımiye Medresesi Taç Kapı Kakma Teknikli Süsleme Bordürü

\footnotetext{
36 Semerci, Mardin Kireçtaşının Yapı Taşı Olarak Araştııılması, 66.
} 


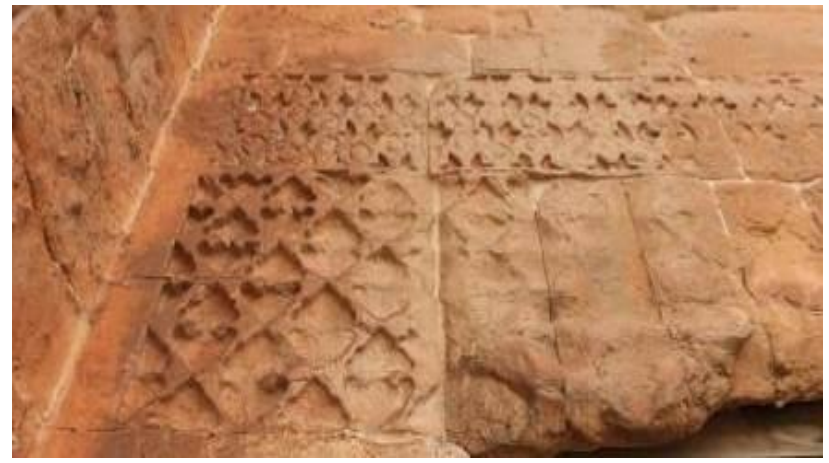

Fotoğraf 26. Kasımiye Medresesi Taç Kapı Kakma Teknikli Süsleme Bordürü Detayı

Medresenin giriş koridorunun tam karşısına denk gelen hücrenin giriş açıklığının üzerinde yer alan süsleme bordürünün üst tarafında da kakma tekniği uygulanmıştır. Siyah taş malzeme ile yukarı bakan palmetin iç kısmına aşağı bakar vaziyette sarı renkli taş ile palmet motifi kakma tekniğiyle yerleştirilmiştir (Fotoğraf 27).

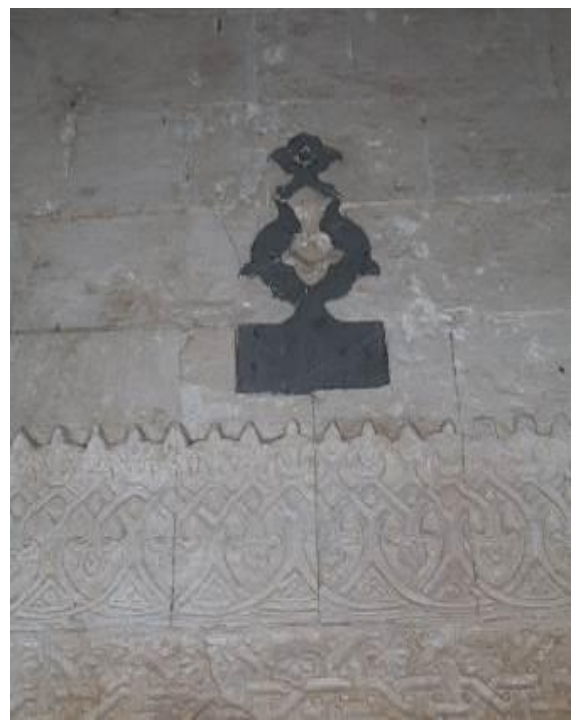

Fotoğraf 27. Kasımiye Medresesi Giriş Koridoru Karşısına Denk Gelen Hücrenin Üzerinde Yer Alan Süsleme 


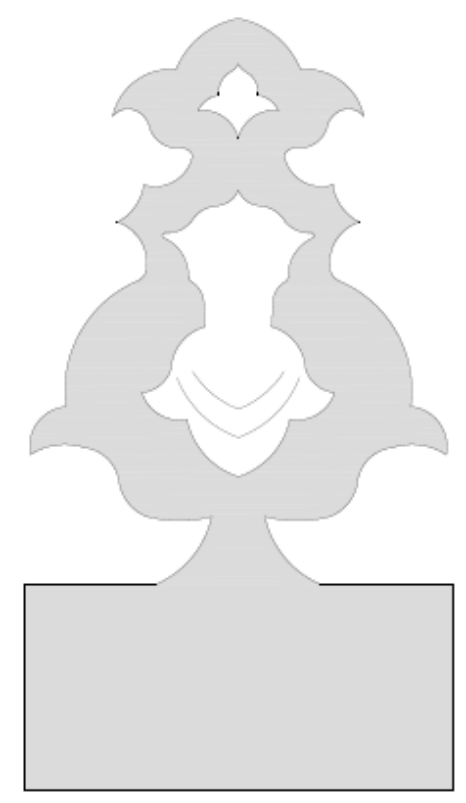

Çizim 4. Kasımiye Medresesi Giriş Koridoru Karşısına Denk Gelen

Hücrenin Üzerinde Yer Alan Süsleme Motifi

Kakma tekniğinin uygulandığı bir diğer süsleme yüzeyi ise mescitteki mihrap bölümü ve giriş açıklı̆ıının etrafını kuşatan bordürdür. Mihrabın etrafını kuşatan bordürde biri aşağı diğeri yukarı bakar vaziyette yerleştirilmiş sıralı palmetlerin içleri oyulmuştur (Fotoğraf 28, Çizim 5). Bu oyuklara siyah taşlar kakılması suretiyle kompozisyon elde edilmiştir. Kompozisyonun alt sırasında yer alan palmetler kireç taşından olup ortasına siyah taşlar yerleştirilmiştir. Üstteki sırada ise bunun tam tersi bir biçimde palmetlerin kendisi tamamen siyah taştan olup ortalarına kireç taşı yerleştirilmiştir (Fotoğraf 29). Aynı özelliklere sahip bordür, giriş açıklığının iç mekâna bakan yüzeyinin etrafında da kullanılmıştır. Büyük oranda tahrip olan bu süsleme kuşağında, siyah taşların büyük bir kısmının döküldüğü kalan izlerden anlaşılmaktadır (Fotoğraf 30,31). 


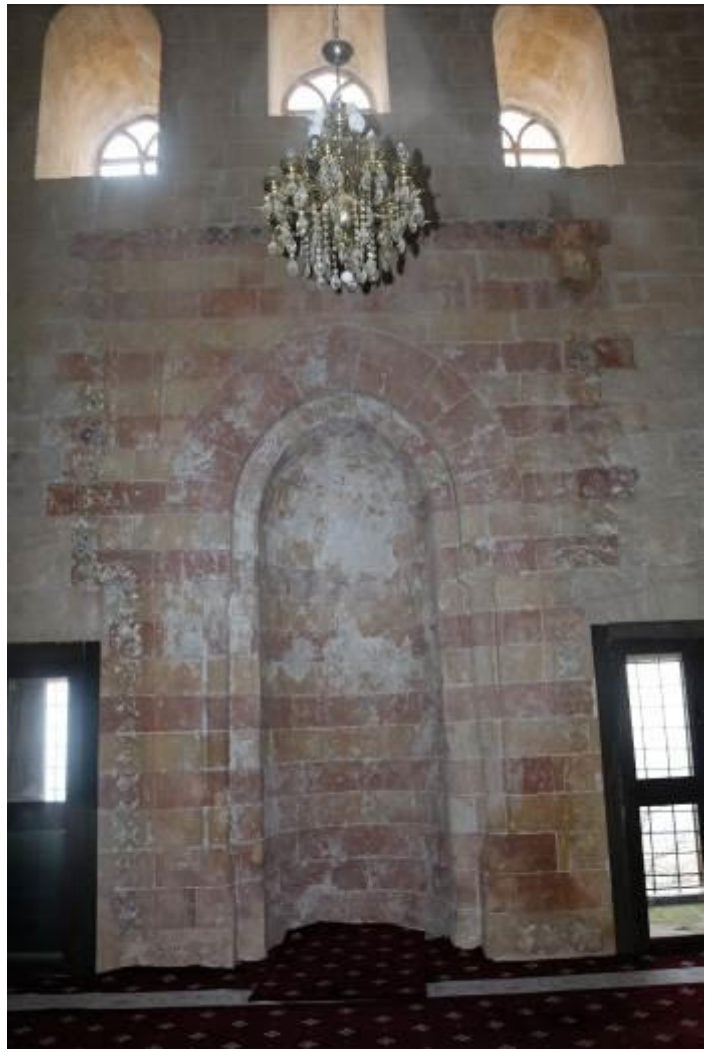

Fotoğraf 28. Kasımiye Medresesi Mescid Bölümü Mihrabı

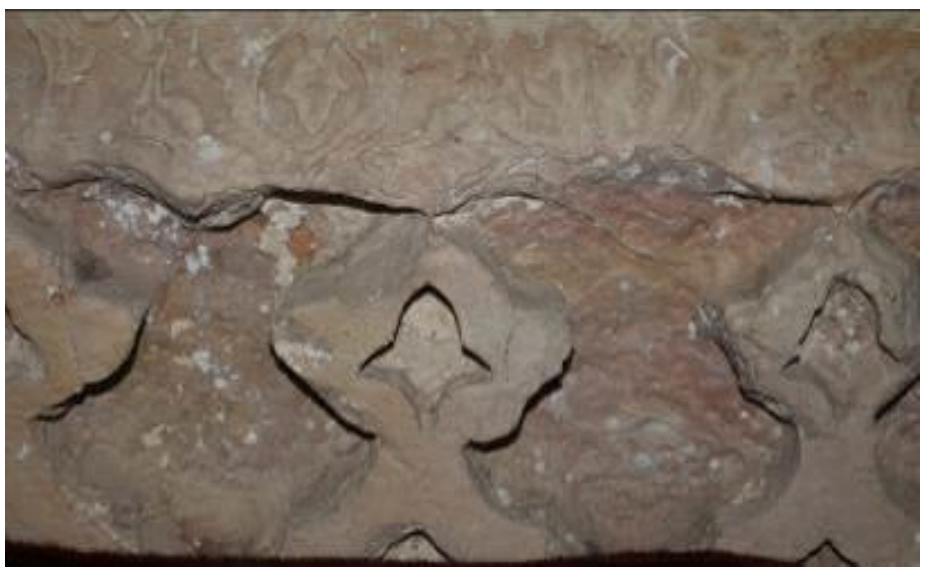

Fotoğraf 29. Kasımiye Medresesi Mescid Bölümü Mihrabı Kakma Tekniği Süslemelerden Düşen Taşların İzleri 


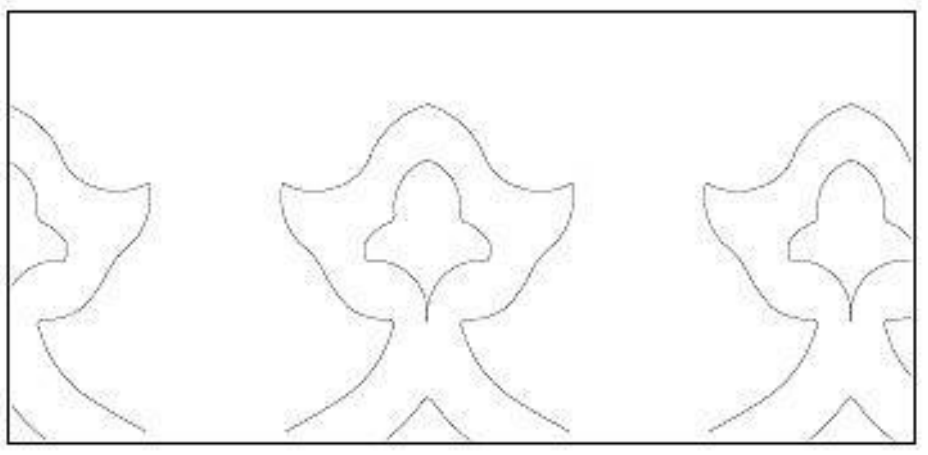

Çizim 5. Kasımiye Medresesi Mescid Bölümü Mihrabı Kakma Tekniği Süslemelerden Detay

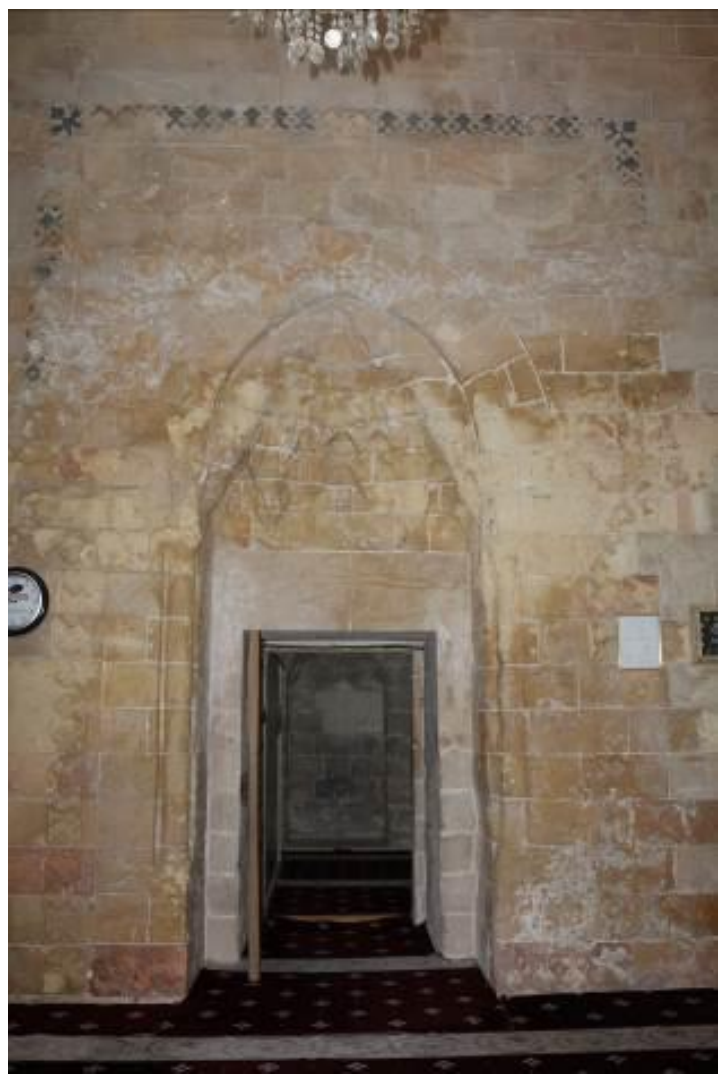

Fotoğraf 30. Kasımiye Medresesi Mescid Bölümü Giriş Açıklığ1 


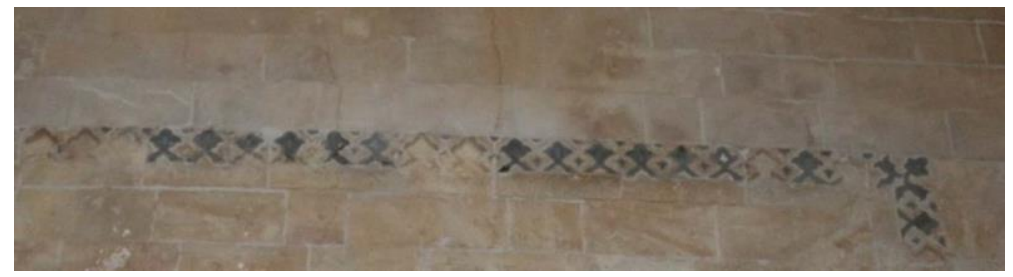

Fotoğraf 31. Kasımiye Medresesi Mescid Bölümü Giriş Açılığı Kakma Süsleme Detayı

Kakma tekniğinin muntazam bir işçilikle uygulandığı bölümlerden biri de eyvan ünitesidir. Eyvanın kuzey duvarında (Fotoğraf 32) selsebilin mukarnas kavsarasının üzerinde yer alan sivri formlu kör kemerde (Fotoğraf 33) ve bu kemerin üzerinde Muhammed ve Ali isimlerinin karşılıklı dört kez yazıldığı ma'kıli hatlı levhada da kakma tekniğini görmekteyiz (Çizim 5). Kemerde kiremit renkli kalker taşı üzerine, " $S$ " hareketli oyuklar oluşturulmuş bu kısımlar da siyah renkli taşlar ile doldurulmuştur. Siyah renkli "S" formlu kakma taşlarının bir kısmı yerinden düşmüştür. Kemer kilit taşı üzerinde yer alan siyah renkli palmet motifinin içi oyularak boş kalan kısım, sarımsı kalker taşı ile yine palmet motifi ile tamamlanmıştır. Sarımsı kalker taşında da ters bir palmet motifinin siyah taş ile iç içe üç palmet motifi oluşturacak şekilde kakıldığı anlaşılmaktadır. İç içe geçmiş üç palmet kompozisyonunun, simetri esası ile baş aşağı bakar vaziyette kemer kilit taşında da aynısının olduğu mevcut izlerden anlaşılmaktadır (Fotoğraf 34).

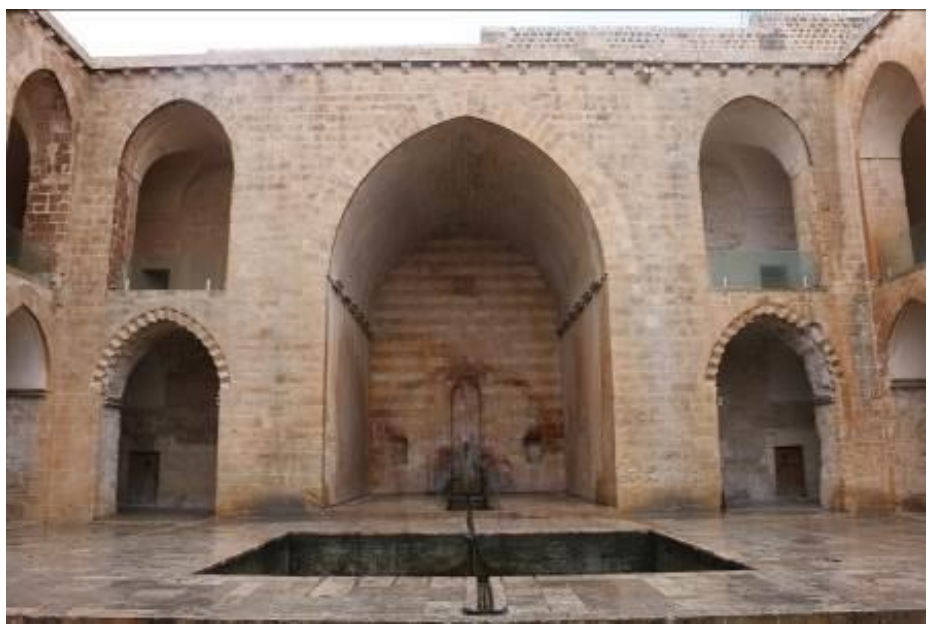

Fotoğraf 32. Kasımiye Medresesi Eyvanı 


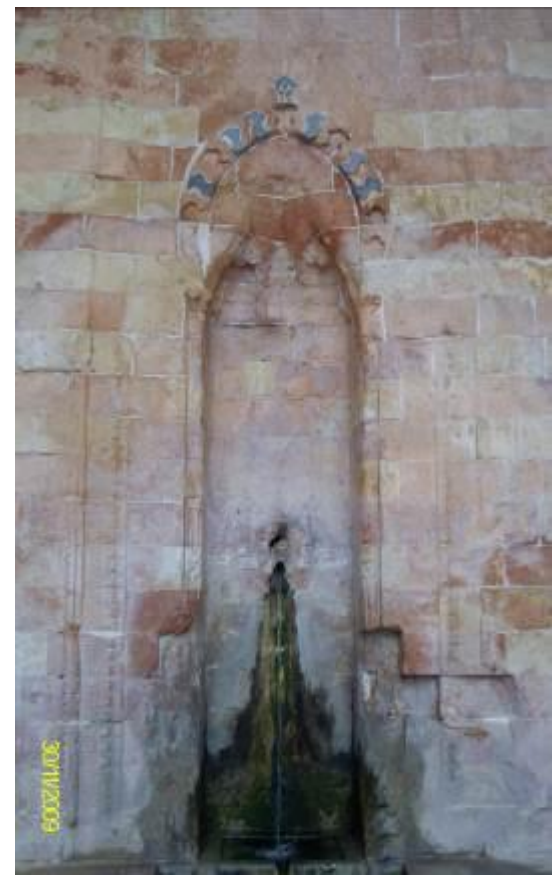

Fotoğraf 33. Kasımiye Medresesi Eyvanda Yer Alan Selsebil

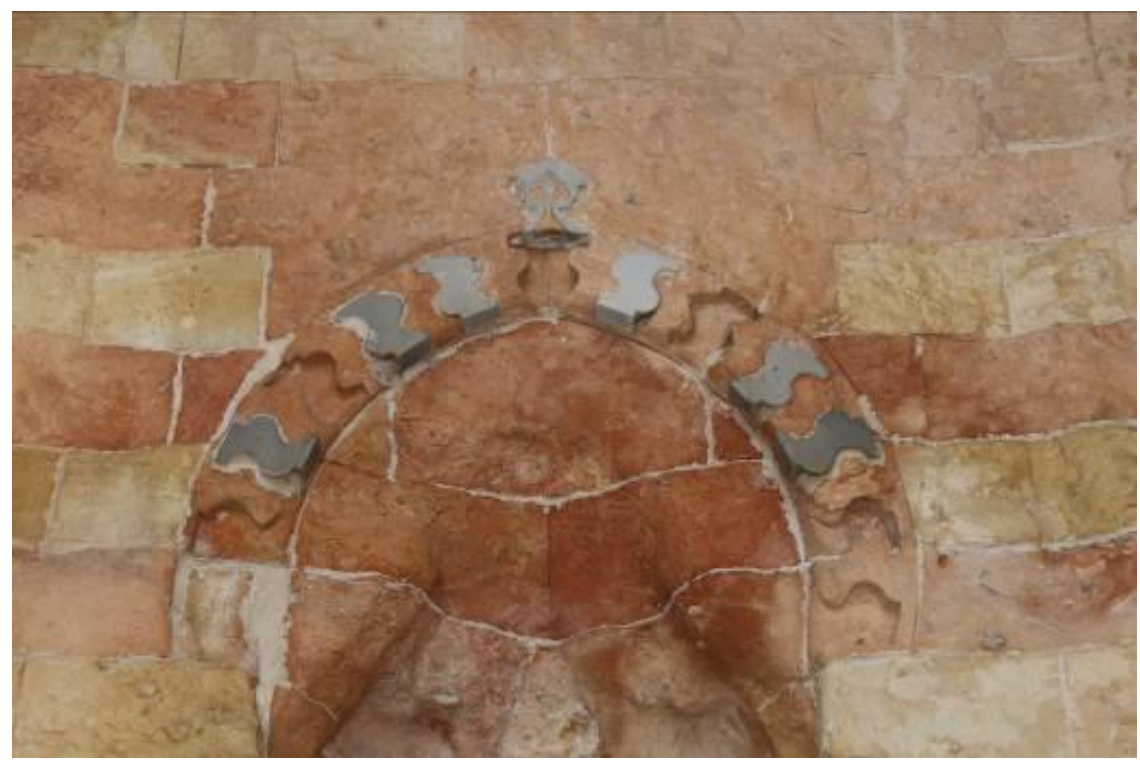

Fotoğraf 34. Kasımiye Medresesi Eyvanda Yer Alan Selsebil Süsleme Detay 1 
Ma'kıli hatlı levhada ise asıl yüzey turuncu renkli kalker taşı olup hat sanatının oluşturduğu harfler taşa oyularak tasarlanmış ve oyuntuların içleri siyah renkli taşlar ile doldurulmuştur (Fotoğraf 35, Çizim 6). Ma'kıli hatlı yazı panosunun etrafındaki süsleme bordüründe karşılıklı farklı yönlere bakan palmet dizilerinin bir siyah bir sarı şekilde sıralı olarak kakma tekniğinde uygulandığ1 görülmektedir. Kitabeliğin yanlarında yer alan üçgen formlu bölümler, izlerden anlaşıldığı kadarıyla, siyah taşlarla tamamlanmış olmalidir.

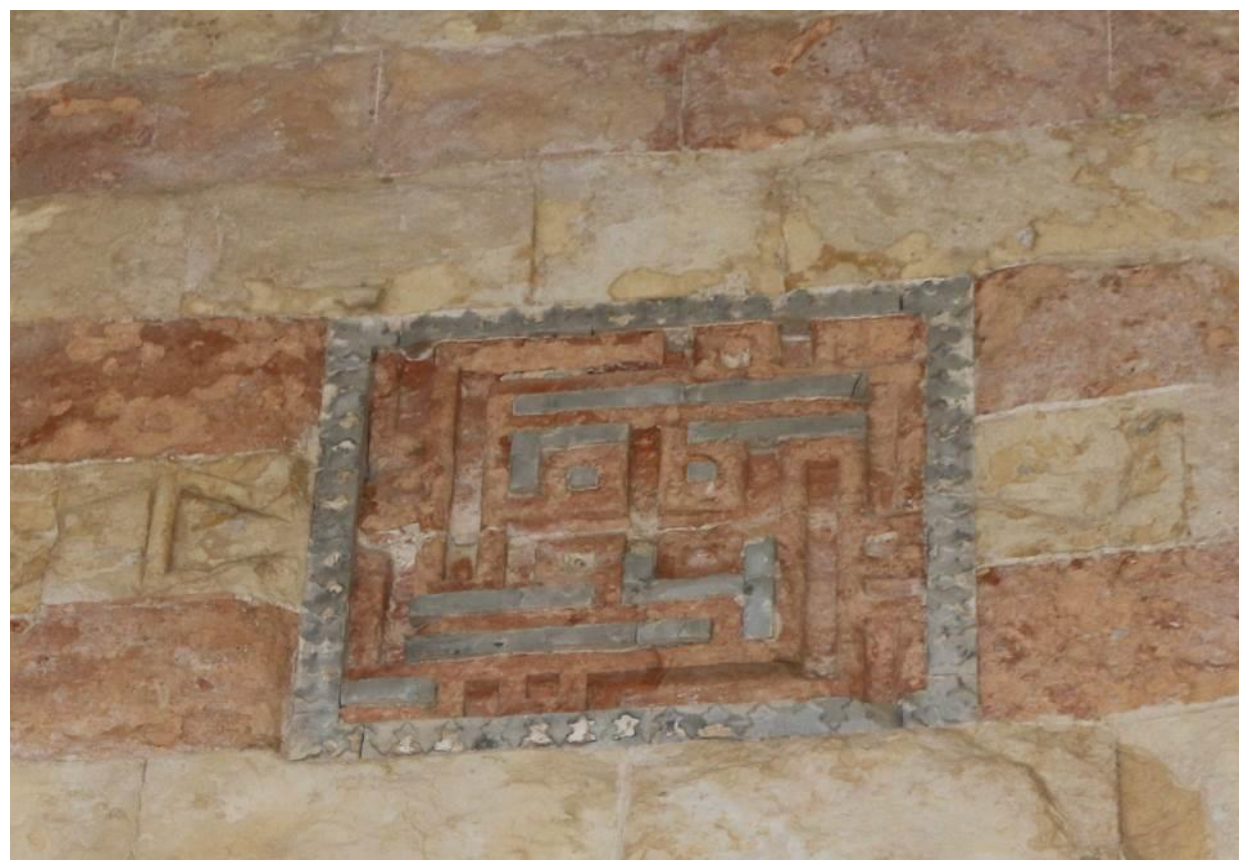

Fotoğraf 35. Kasımiye Medresesi Eyvanda Yer Alan Ma'kıli Pano Süsleme Detayı 


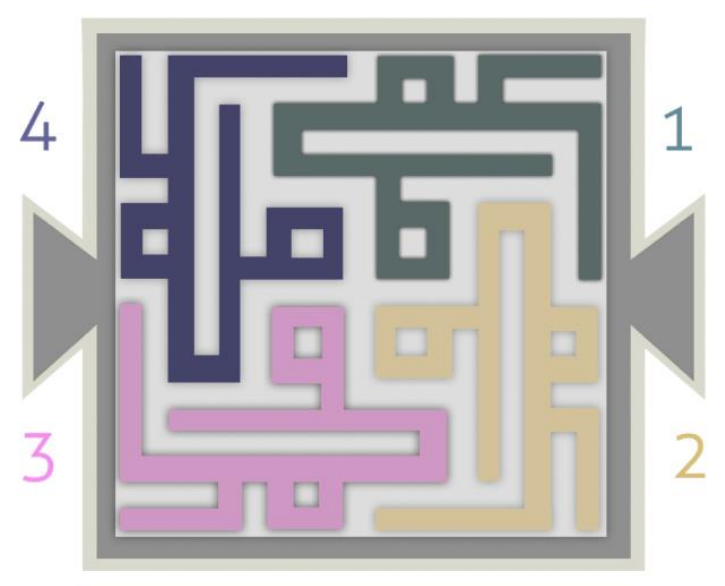

Çizim 6. Kasımiye Medresesi Eyvanda Yer Alan Ma'k1li Pano Süsleme Detayının Tamamlanmış Hali (Eman Abuarra'dan)

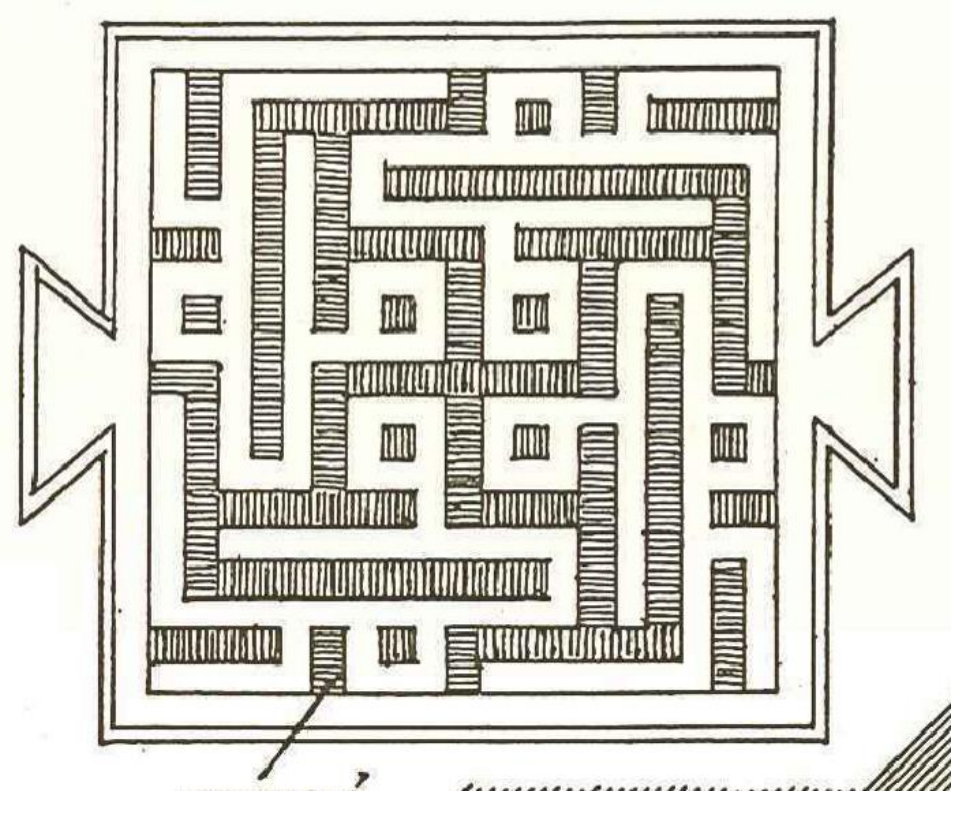

Çizim 7. Kasımiye Medresesi Eyvanda Yer Alan Ma'kıli Pano Süsleme Detayı (Albert Gabriel'den) 


\section{Karşılaştırma ve Değerlendirme}

Anadolu'da farklı dönemlere ait mimari yapılarda uygulanan taş süslemeler, teknik ve malzeme yönünden oyma, kafes oyma, kakma, kazıma, boyama teknikleri ile renkli taş olarak farklı tekniklerle uygulanmıştır. ${ }^{37}$ Anadolu'da, Zazadin Hanı, Karatay Medresesi, Diyarbakır Mesudiye Medresesi, Balat İlyas Bey Camii ${ }^{38}$, Amasya Bayezıd ve Yörgüç Paşa zaviyeleri, Osmancık Koca Mehmet Paşa Zaviyesi, Gaziantep Tahtani Camii ${ }^{39}$, Edirne Eski Cami, Edirne Üç Şerefeli Cami, Urfa Gümrük Hanı, Gebze Mustafa Paşa Külliyesi 40, Şehzade Türbesi 41 örneklerinden de anlaşıldığı gibi renkli taş işçiliği farklı dönem ve bölgelerde her zaman beğeni ile uygulanmıştır.

Renkli taş kullanımının, tarihi yapı süslemesinde sıkça tercih edildiği bilinmektedir. Anadolu'da farklı bölgelerde aynı döneme tarihlenen eserlere baktığımızda renkli taşın hem kakma olarak, hem de kemer örgülerinde dönüşümlü olarak kullanımının yaygınlık gösterdiği dikkati çekmektedir. ${ }^{42}$ Özellikle Beylikler dönemi taş süslemesinde, Orta ve Güney Anadolu beyliklerinde oyma, eğri kesim ve kafes oyma, Batı Anadolu beyliklerinde ise renkli taş, çini, sırlı tuğla kakma ve mozaik tekniklerinin bir yenilik olarak uygulandığı görülmektedir. Osmanlı Beylikler devri taş süslemeciliğinde ise oyma, kazıma, boyama, kakma ve almaşık tekniklerin uygulanmasının yanı sıra bu tekniklerin birkaçının bir arada kullanıldığı görülmektedir. ${ }^{43}$ Ancak, tarihi yapı uygulamalarında, cephe düzenlemeleri ve bezemeleri açısından yerel özelliklerin ortaya konulmuş olması, uygulamada beylikler arasında farklılıklar olduğuna işaret etmektedir. ${ }^{44}$ Nitekim Mardin'deki tarihi yapı

\footnotetext{
Yıldız Demiriz, Osmanlı Mimarisi'nde Süsleme. Erken Devir (1300-1453). bs. (İstanbul: Kültür Bakanlığ1 Yayınları, 1979), 11-13.

38 Özbek, Osmanlı Beyliği Mimarisinde Taş Süsleme (1300-1453), 587; Aslanapa, Türk Sanatı, 215.

39 Şenay Özgür, Yıldız, " Gaziantep Camilerinde Görülen Bazı Güneyli Etkiler”, Ege Üniversitesi Sanat Tarihi Dergisi, 25/1, (2016): 96.

40 Hamza Gündoğdu, "Gebze Çoban Mustafa Paşa Külliyesi'nin Osmanlı Külliyeleri İçindeki Yeri ve Önemi", Uluslararası Gazi Süleyman Paşa ve Kocaeli Tarihi Sempozyumu-III, (Kocaeli: Kocaeli Büyükşehir Belediyesi Yayınları, 2017), 2783; Ayşen Nurdan Aldoğan, “Gebze-Çoban Mustafa Paşa Camii ve Memlûk Etkili Bezemesi”, Türkiyemiz, 38, (1982): 27-38; Köksal Seyhan, “Çoban Mustafa Paşa Külliyesi”, Türkiye Diyanet Vakfi İslam Ansiklopedisi, (İstanbul, Türkiye Diyanet Vakfı,1993), 8,351-354.

41 Şerare Yetkin, "Sinan'ın Mimarisinde Çini Süsleme Düzeni", Mimarbaşı Koca Sinan, Yaşadığı Çağ ve Eserleri, ed. Sadi Bayram, bs. (İstanbul: Vakıflar Genel Müdürlüğü, 1988), 481.

42 Yıldıray Özbek, "Anadolu Türk Mimarisinde Taş Süsleme”, Türkiye Araştırmaları Literatür Dergisi, 7(14), (2009):145.

43 Özbek, "Anadolu Türk Mimarisinde Taş Süsleme”, 150.

44 Muhammed Görür, Beylikler Dönemi Mimarisinde Taş Süsleme (1300-1435), (Yayınlanmamış Doktora Tezi, Hacettepe Üniversitesi, Sosyal Bilimler Enstitüsü, Ankara 1999), 295-322.
} 
süsleme programında kendine has özelliklerle renkli taş süslemenin görülmesi, bu görüşümüzü kantllar niteliktedir.

İncelemeler sonucunda, Mardin'de Ortaçağ İslam dönemi dinî yapılarından sadece Artuklu ve Akkoyunlu dönemi yapılarında benzer şekilde kakma tekniğinin kullanıldığı tespit edilmiştir. Sanattaki kültürel aktarımın doğal bir sonucu olarak bu devletlerin mimari yapı süsleme programı, benzer teknik ve özelliklerle karşımıza çıkmaktadır. Mardin'de Artuklu döneminde görülen bu süslemeler, siyasi bağlantılar ve coğrafi yakınlığa da paralel olarak Zengî ve Eyyûbî ${ }^{45}$ sanatıyla da benzerlik sunmaktadır. ${ }^{46}$ Sanattaki bu benzerlikten dolayı kakma tekniği, Anadolu dışında Suriye ve Irak'la birlikte düşünülmesi gereken bir nitelik taşımaktadır. ${ }^{77}$ Bundan dolayı Artuklu ve Akkoyunlu Devletlerinin yönettiği bölgelerde üretilen sanat, o günün coğrafi sınırları içinde değerlendirildiğinde anlam kazanacaktır.

Suriye ve Mısır gibi güney ülkelerinin mimarisinde görülen renkli taş süsleme, Memlûklu ${ }^{48}$ Sanatı ile de ilişkilendirilebilir. ${ }^{49}$ Memlûk öncesi dönemde Suriye ve Mısır'da Eyyûbî, Zengî, Fâtimî ve Tolunoğulları gibi devletler kurulmuştur. Memlûkların yönetimle birlikte bu devletlerin mimari mirasını olduğu gibi devraldığı bilinir. ${ }^{50}$ Ortaya koydukları kültürel miras Anadolu'daki mimari yapılarla karşılaştırıldı̆̆ında Anadolu'da gelişen mimarinin daha anıtsal bir karaktere sahip olduğu görülür. Ancak, süslemelerin Memlûklu üslubu ile benzerlikler gösterdiği de dikkati çeker. ${ }^{51}$

45 Ahmet Ali, Bayhan, "Misırdaki Eyyubi Devri Mimari Eserleri: Medreseler ve Hankah/ Zaviyeler", Atatürk Üniversitesi Güzel Sanatlar Enstitüsü Dergisi, 12, (2004): 1-16.

46 Turan, Artuklu Dönemi Tarihi Yapılarındaki Figürlü Süslemeler Ve Orta Asya Kültürünün Etkileri, 178.

47 Gezici ustaların İran, Irak ve Suriye' den gelmeleri bölgedeki mimarî üslup ve bezemeye etki ettikleri ifade edilmektedir, bkz., Belkıs Doğan; Aziz Doğanay, "Akkoyunlu ve Karakoyunlu Devletlerinde Mimarî ve Sanat Üslûbu Üzerine Bir Değerlendirme", İnsan ve Toplum Bilimleri Araştırmaları Dergisi, 6/1, (2017): 660.

48 Siyasi ilişkiler bağlamında, bazı kaynaklarda Artukluların, Memlûklerin muasır bir şubesi olduğu şeklinde ifadeler kullanılmıştır. bkz., El- Kalkaşandî (1355-1418) tarafından kaleme alınan Subh El-'Aşâ, adlı eserde Mardin'e dair bilgiler arasında, Mardin Artukluları Hükümdarlarının Memlûklerle olan ilişkilerinde “ Artukoğulları hükümdarlarının Mısır Sultanlarıyla aralarında muhabbet ve dostluk bulunduğunu ve devamlı yazışmaların olduğunu" ifade etmektedir, bkz., Altan Çetin, "Memlûk Kaynaklarına Göre Mardin", I. Uluslararası Mardin Tarihi Sempozyumu, ed. İbrahim Özçoşar, Hüseyin Haşimi Güneş, (İstanbul: Mardin Tarihi İhtisas Kütüphanesi Yayınları, 2006), 389.

49 Memlûklular, 1250-1517 yılları arasında Suriye ve Mısır'da hüküm süren bir Türk sülalesinin adıdır. XIII. yüzyılda Moğol Saldırılarına, XIV. yüzyılda Timur saldırılarına ve haçlı saldırılarına karşı mücadele etmiş olmaları kendilerine şöhret kazandırmıştır, bkz.,İsmail Yiğit, Memlûkler, bs. (İstanbul:Kayıhan Yayınları, 2015), 16; Aslanapa, Türk Sanatı, 96-100.

50 Michael Meinecke, Die Memlukische Architectur in Agypten and Syrien 648/1250 bis 923/1517, bs. (Glückstadt: Verlag J.J. Augustin GmbH, 1992), 118.

51 Özbek, Osmanlı Beyliği Mimarisinde Taş Süsleme (1300-1453), 596. 
İncelenen yapılar, renkli taş kullanımı bakımından Diyarbakır, Urfa, Adana ve Gaziantep yapılarıyla büyük benzerlik göstermektedir. Diyarbakır Kasım Padişah Camii, Ali Paşa Camii, Adana Ulu Camii' $n^{52}$ vb. örneklerde iki renkli taş, Gaziantep Karatarla Camii, Handan Bey Camii, Eyüpoğlu Camii ${ }^{53}$ vb. örneklerde ise üç renkli taş bir arada kullanılmıştır. Üç renkli taşın yoğun kullanıldığı Gaziantep Camilerindeki kakma teknikli süslemelerde motif ve kompozisyonlar, Zengî Mimarisi karakteri yansitırken ${ }^{54}$ Mardin'deki örnekler, Selçuklu süsleme üslubunun da izlerini taşıyacak şekilde sentez diyebileceğimiz kendine has özellikler sergilemektedir.

Mardin'de mimari yapı malzemesi olarak sarımtırak kireç taşının kullanıldı̆̆ını ${ }^{55}$ ve kakma tekniğinin iki farklı malzeme çeşitlemesiyle taşa uygulanarak üretildiği anlaşılmıştır. Birinci uygulama, taşa sırlı çini malzemenin aplike edildiği Hamza-i Kebir Camii'ndeki uygulamadır. İkincisi ise sarımsı kireç taşı üzerine farklı renkli bir taşın kakılarak oluşturulduğu uygulamadır. Latifiye Camii, Kasımiye Medresesi, Zinciriye Medresesi uygulamaları bu kategoride değerlendirdiğimiz örneklerdir. Merzifon Çelebi Mehmet Medresesi ${ }^{56}$ taç kapı eyvanının yan duvarlarında, Amasya Beyazıd Paşa Camii'nin kemer ve süsleme bordürlerinde, Balat İlyas Bey Camii pencere süslemelerinde, Edirne Üç Şerefeli Camii'n pencere süslemelerinde ve Edirne Eski Camii 57 batı taç kapısında olduğu gibi yapıların belli noktalarında kullanılmıştır. ${ }^{58}$

Yapılar arasında çini mozaik tekniğindeki seramik parçalarının, taş yüzeyine kakma yöntemiyle uygulandığı tek örnek olan Hamza-i Kebir Camisinin taç kapısı, ünik bir eser olarak değerlendirilebilir. Akkoyunlu dönemi eserlerinden Zeynel Bey Künbedi dışında diğer eserlerde dış mimaride çini kullanımı yok denecek kadar azdır. ${ }^{59}$ Mardin'de çini malzemenin, mimari süslemede kullanıldığı bu tek örneğin de başka bir yerden alınarak devşirme malzeme olarak kullanılmış olabileceği

\footnotetext{
52 Ali Osman Uysal, “Adana Ulu Camii”, Vakıflar Dergisi, 19, (1985), 277-284.

53 Yıldız, "Gaziantep Camilerinde Görülen Bazı Güneyli Etkiler", 96.

54 Farklı renkte taş malzemeyle oluşturulmuş geometrik bezemelerin Zengîlerden gelen bir üslûp olduğu kabul edilmektedir, bkz., Selçuk Mülayim, Anadolu Türk Mimarisinde Geometrik Süslemeler. Selçuklu Çă̆l, bs. (Ankara: Kültür ve Turizm Bakanlığı Yayınları, 1982),53-56.

55 Fatih Semerci, Mardin Kireçtaşının Yapı Taşı Olarak Araştııılması, Yayımlanmamış Yüksek Lisans Tezi, İstanbul Teknik Üniversitesi, Fen Bilimleri Enstitüsü, İstanbul: 2008,58.

56 Mahmut Akok, "Merzifonda Çelebi Mehmet Medresesi", Mimarlık, Güzel Sanatlar ve Şehircilik Dergisi, IX/12, (1952): 30.

57 Çakmak, Erken Dönem Osmanlı Mimarisinde Taçkapılar (1300-1500), res. $26 .$.

58 Yıldıray, Osmanlı Beyliği Mimarisinde Taş Süsleme (1300-1453), res.565-573

59 Doğan; Doğanay, “Akkoyunlu ve Karakoyunlu Devletlerinde Mimarî ve Sanat Üslûbu Üzerine Bir Değerlendirme", 660 .
} 
düşünülmektedir. Anadolu'da taç kapıda çini mozaik malzemenin kullanıldığı ilk örnek Divriği Kale Camii'dir. ${ }^{60}$ Taşa kakılmış çininin en işçilikli örneği ise Balat İlyas Bey Camii'nde görülür. Bu örnek kompozisyon bakımından Hamza-i Kebir Camii örneği ile büyük benzerlik göstermektedir. Çok kollu yıldızlar arasında oluşan geometrik oyuklara renkli taşlarla birlikte firuze renkli çinilerin de kakıldığ 1 görülür. ${ }^{61}$ Bölge mimarisi içinde en yakın örnek olarak bazalt taşa turkuaz renkli çinilerin kakıldığ Ahmet Paşa Camii minaresini de örnek verebiliriz. Yine Konya Meram Ali Dede Türbesi'nin kemer taşlarının yüzeyinde yapılan oyuntulara firuze ve lacivert renkli çinilerin kakma tekniği ile yerleştirildiği örnek de dikkat çekicidir. ${ }^{62}$ Karamanoğlu II. İbrahim Bey İmareti minaresinin şerefe altındaki bordürde üç dilimli yan yana dizilmiş şeritlerin tepe noktalarına yerleştirilmiş palmet dizisi, taş üzerine firuze renkli kakma çiniler ile karşımıza çıkmaktadır. Bir diğer örnek ise Edirne Şah Melek Paşa Camii'nde görülen turkuaz renkli sırlı tuğla malzeme ile uygulanmış kakma örneğidir63.

Yapıların süsleme programında geometrik, bitkisel ve yazı karakterli motiflerin oluşturduğu kompozisyonlar tercih edilmiştir. Latifiye Camii ile Hamza-i Kebir Camii kakma teknikli süslemelerinde geometrik, sekiz kollu yıldız motifleri kullanılmıştır. Benzer özelliklere sahip yıldız motifleri, Anadolu' da birçok eserin süsleme kompozisyonunda karşımıza çıkmaktadır. Ankara Alaeddin Camii minberi64, Arslanhane Camii minberi65, Birgi Ulu Camii minberi ${ }^{66}$, Akşehir Şeyh Hasan Türbesi taç kapısi ${ }^{67}$, Konya Sahip Ata Hankahı, Tercan Mama Hatun Kümbeti taç kapısı ${ }^{68}$, Niğde Ak Medrese mihrabı ve Ahlat Mezartaşları ${ }^{69}$ örnek verilebilir.

İncelemelerde, Zinciriye ve Kasımiye Medreselerinde taç kapı, kemerler ve mescid mekânlarının süslemelerinin birbirine yakın özellikler sergilediği görülmüştür. Taç kapılardaki ince taş işçiliği ve kakma

\footnotetext{
60 Ayduslu, "Selçuklu Ve Beylikler Döneminde Kakma Çiniler Ve Günümüz Sanatından Bir Kaç Örnek”, 19.

61 Oluş Arık, "Çininin Tarihçesine Kısa Bakış", Anadolu Toprağının Hazinesi Çini Selçuklu ve Beylikler Çă̆ı, ed. Rüşhan Arık- Oluş Arık, (İstanbul: Kale Grubu Kültür Yayınları 2007),180.

62 Ayduslu, "Selçuklu Ve Beylikler Döneminde Kakma Çiniler Ve Günümüz Sanatından Bir Kaç Örnek”, 27.

63 Yıldıray, Osmanlı Beyliği Mimarisinde Taş Süsleme (1300-1453): 510; Çakmak, Erken Dönem Osmanlı Mimarisinde Taçkapılar (1300-1500), res. 51.

64 Gönül Öney, “Anadolu Selçuklu ve Beylikler Devri Ahşap Teknikleri”, Sanat Tarihi Yıllı̆̆ı,3, (1969-1970): 137-138.

65 Gönül Öney, Ankara Arslanhane Camii, bs. ( Ankara: Kültür Bakanlığı Yayınları, 1990), res. 14-15.

66 Yıldız Demiriz, "XIV. Yüzyılda Ağaç İşleri", Yüzyıllar Boyunca Türk Sanatı, bs. (İstanbul: Milli Eğitim Basımevi, 1977): 61.

67 Yekta Demiralp, Akşehir ve Köylerindeki Türk Anttları, bs. (Ankara: Kültür Bakanlığı Yayınları, 1996), res. 103.

68 Derek Hill; Oleg Graber, Islamic Architecture and Its Decoration, A.D. 800-1500, bs. (Londra: Faber and Faber, 1964), res. 345.

69 Beyhan Karamağaralı, Ahlat Mezartaşları, bs. (Ankara: Güven Matbaası, 1972).
} 
süslemelerde kullanılan ortak süsleme dili ilk bakışta dikkat çekmektedir. ${ }^{70}$ Bitkisel motiflerin daha çok kullanıldığı bu iki örnekte özellikle, kakma tekniğinde tercih edilen palmet motifleri, hem form hem de malzeme seçimi bakımından büyük benzerlik taşımaktadır. Süsleme kompozisyonunda palmetin ya kendi başına kompozisyonun ana motifi ya da tamamlayıcı yardımcı motifi olarak tercih edildiğine ve Mardin' deki süsleme programında sevilerek kullanıldığına işaret etmektedir ${ }^{71}$. Ortaçă̆ İslam Sanatında bitkisel karakterli süslemelerde palmet motifi, en çok görülen motiftir. Mardin Hatuniye Medresesi, Niğde Hüdavent Hatun Türbesi, Balat İlyas Bey Camii, Niğde Ak Medrese, Karaman Hatuniye Medresesi, Karaman Hacı Beyler Camii 72 , Bursa Yeşil Camii ${ }^{73}$ vb. eserler, palmetin farklı kompozisyonlarla karşımıza çıktı̆̆ı eserlerden bazılarıdır.

\section{Sonuç}

Mardin'de mimari yapılarda sarımtırak kireç taşının sunduğu monotonluğu yıkma ve izleyenler üzerinde bir etki yaratma kaygısıyla, iki renkli taş süslemelerden kakma tekniği, en fazla tercih edilen teknik olmuştur.

Mardin'de kakma tekniği, iki farklı malzeme ile taşa uygulanarak üretilmiştir. İlk uygulama, taşa sırlı çini malzemenin aplike edildiği Hamza-i Kebir Camii'ndeki uygulamadır. İkincisi ise Latifiye Camii, Kasımiye Medresesi, Zinciriye Medresesi örneklerinde görülen sarımsı kireç taşı üzerine siyah (duman rengi) renkli taşın kakılarak oluşturulduğu uygulamadir.

Benzer konu seçimi, biçimlendirme ve kompozisyon biçimleri, sarımsı kireç taşı üzerine siyah taşın kakma teknikli uygulamaları, 13.-15. yüzyıllar arasında Mardin yöresinde güçlü bir taş işleri atölyesinin var olduğunu düşündürmektedir. Nitekim Artuklu dönemi yapılarından Latifiye Camii ve Zinciriye Medresesi'nin süsleme programında karşılaştığımız kakma tekniğinin, Akkoyunlu dönemi eseri olan Kasımiye Medresesi örneğinde olduğu gibi benzer özelliklerle devam etmiş olması bunu doğrulamaktadır.

Yapıların kakma teknikli süslemelerinde geometrik, bitkisel ve yazı karakterli kompozisyon ve motifler tercih edilmiştir. Latifiye Camii ve Hamza-i Kebir Camii'nde görüldüğü üzere geometrik desenlerde çok kollu

\footnotetext{
Altun, "Mardin'de Türk Devri Anıtsal Mimarisine Genel Bakış", 166.

Barışta, "Mardin Kasımiye ve Zinciriye Medreselerinin Taş Süslemelerinde Gözlenen Benzerlikler", 244.

Özbek, Osmanl Beyliği Mimarisinde Taş Süsleme (1300-1453), res.579, 594.

3 Çakmak, Erken Dönem Osmanlı Mimarisinde Taçkapılar (1300-1500), şekil 39-40.
} 
yıldız, üçgen ve çokgen motifleri kullanılmıştır. Kasımiye ve Zinciriye Medreselerinde ise daha çok bitkisel süsleme kullanılmıştır. Bu süslemelerde kompozisyon, palmet motifinin baş aşağı veya yukarı bakar vaziyette yerleştirilmesi ile oluşturulmuştur. Yazılı süslemede ise ma'kıli karakterli hattın Kasımiye Medresesi'ndeki tek örnek ile kakma tekniğinde uygulandığı görülmüştür.

Mardin'deki Artuklu dönemi Camilerinde iki renkli taşın alternatif kullanımı ile oluşan almaşık düzen; mihrap, kemer, pencere söveleri gibi birçok yapı elemanında karşımıza çıkarken kakma tekniği ise sadece Latifiye Camii taç kapısında uygulama alanı bulmuştur. Eser, kakma tekniğinin uygulandığı tek Artuklu camiisi olması bakımından dikkat çekicidir.

Sonuç olarak Mardin'de Ortaçağ İslam Mimarisinde, Artuklu ve Akkoyunlu dönemi eserlerinden bazılarının süsleme programında kakma tekniği uygulandığg görülmüştür. Bu örnekler, kendine has yerel özellikler yansıttığı gibi genel hatları ile Ortaçağ İslam Sanatının karakteristik özelliklerini de yansıtmaktadır. Anadolu'da aynı dönem içerisinde karşılaştı̆̆ımız örneklere nazaran Mardin'de daha yoğun kullanılan bu teknik, motif ve kompozisyonlarda Selçuklu süsleme üslubunun izlerini taşımaktadır.

\section{Kaynakça}

Akok, Mahmut. "Merzifonda Çelebi Mehmet Medresesi". Mimarlık, Güzel Sanatlar ve Şehircilik Dergisi, IX/1-2, (İstanbul 1952), 29-37.

Aldoğan, Ayşen Nurdan. “Gebze-Çoban Mustafa Paşa Camii ve Memlûk Etkili Bezemesi". Türkiyemiz, 38, (İstanbul 1982): 27-38.

Alper, Berrin. "Mercek Altında Bir Yapı: Sultan Kasım Medresesi". Taşın Belleği Mardin. 241-264. İstanbul: Yap1 Kredi Yayınları, 2005.

Altun, Ara. "Mardin'de Türk Devri Anıtsal Mimarisine Genel Bakış". Taşın Belleği Mardin. 149-175. İstanbul: Yap1 Kredi Yayınları, 2005.

. Anadolu'da Artuklu Devri Türk Mimarisi'nin Gelişmesi. bs..İstanbul: Kültür Bakanlığı Yayınları, 1978.

. Mardinde'ki Türk Devri Mimarisi. bs. İstanbul: Mardin Valiliği Yayınları, 2011.

Arık, Oluş. "Çininin Tarihçesine Kısa Bakış". ed. Rüşhan Arık- Oluş Arık, Anadolu Toprağının Hazinesi Çini Selçuklu ve Beylikler Çă̆ı. bs. İstanbul: Kale Grubu Kültür Yayınları 2007.

Artuk, İbrahim. Artuk İlinin Tarihi Belgesi. bs. İstanbul: Güven Basımevi, tsz.

"Mardin Zinciriye Medresesi ve Bânisi". Selçuklu Araştırmaları Dergisi, III, (1971): 191-194.

Aslanapa, Oktay. Türk Sanatı. bs. İstanbul: Remzi Kitabevi 1993.

Atalan, Özlem. “Artuklu Mimarisi'nin Anıtsal Mimarisinin Korunması Üzerine Model Yaklaşımı: Kasımiye Medresesi Örneği”, I. Uluslararası Artuklu Sempozyumu 
Bildirileri, 25-26-27 Ekim 2007 Mardin, ed. İbrahim Özçoşar, Mardin Valiliği, (Mardin 2008), II, 305-315.

Ayduslu, Nevin. "Selçuklu Ve Beylikler Döneminde Kakma Çiniler Ve Günümüz Sanatından Bir Kaç Örnek". Güzel Sanatlar Enstitüsü Dergisi, 29, (2012): 1733.

Bakırer, Ömür. Onüç ve Ondördüncü Yüzyıllarda Anadolu Mihrapları. bs. Ankara: Türk Tarih Kurumu Yayınları, 1976.

Barışta, Hatice Örcün. "Mardin Kasımiye ve Zinciriye Medreselerinin Taş Süslemelerinde Gözlenen Benzerlikler", I. Uluslararası Artuklu Sempozyumu Bildirileri, 25-26-27 Ekim 2007 Mardin, ed. İbrahim Özçoşar, Mardin Valiliği, ( Mardin 2008), II, 244.

Bayhan, Ahmet Ali. “Misırdaki Eyyubi Devri Mimari Eserleri: Medreseler ve Hankah/ Zaviyeler". Atatürk Üniversitesi Güzel Sanatlar Enstitüsü Dergisi, 12, (Erzurum:2004):1-16.

Beksaç, Engin. "Eyyubiler (Sanat)" . Türkiye Diyanet Vakfi İslam Ansiklopedisi, XII, (İstanbul 1995): 20- 32.

Creswell, Keppel Archibald, Cameron. "Mardin and Diyarbekr" , In Muqarnas XV: An Annual on the Visual Culture of the Islamic World. ed. Gülru Necipoglu. bs. Leiden: E.J. Brill,1998, 2-8.

Çaça, Sultan. Mardin'de Artuklu Dönemine Ait Bir Medrese: Zinciriye (Sultan İsa) Medresesi, Yayımlanmamış Yüksek Lisans Tezi, Sakarya Üniversitesi Sosyal Bilimler Enstitüsü, Sakarya 2013.

Çağlayan, Murat ve Tanyeli, Gülsün. "Mardin Zinciriye (Sultan İsa) Medresesi ve Osmanlıdan Günümüze Medresedeki Restorasyon Müdahaleleri". Mimarist, 55, (2016) :89-93.

- Mardin Anıtsal Yapılarında Değişmişlik Ve Özgünlük Sorunları, Yayımlanmamış Doktora Tezi, İstanbul Teknik Üniversitesi, İstanbul 2017. Anadolu'da Bir Akkoyunlu Kültür Mirasi: Mardin Kasımiye Medresesi", International Conference on Natural Science and Engineering (ICNASE'16) , 1920 Mart 2016, ed. Murat Ceyhan, Kilis: Mavi Kitap Yayıncılık, (2016): 11131146.

"Bir Mimari Karşılaştırma: Mardin Zinciriye ve Kasımiye Medreseleri”, İlk Çağlardan Modern Döneme Tarihten İzler II, ed. M. Doğan Karaçoşkun ve Osman Köse, (Ankara: Berikan Yayınevi, 2018), 147-163.

. Mardin Ortaçă̆ Anttları ve Yapım Teknikleri. bs. İstanbul: Hiper Yayın, 2017.

Çakmak, Şakir. Erken Dönem Osmanlı Mimarisinde Taçkapılar (1300-1500). bs. Ankara: Kültür Bakanlığı Yayınları, 2001.

Çetin, Altan. "Memlûk Kaynaklarına Göre Mardin", I. Uluslararası Mardin Tarihi Sempozyumu, ed. İbrahim Özçoşar, Hüseyin Haşimi Güneş, İstanbul: Mardin Tarihi İhtisas Kütüphanesi Yayınları, (2006): 387-399.

Demiriz, Yıldız. "XIV. Yüzyılda Ağaç İşleri". Yüzyıllar Boyunca Türk Sanatı. bs. İstanbul: Milli Eğitim Basımevi, 1977.

. Osmanlı Mimarisi'nde Süsleme. Erken Devir (1300-1453). bs., İstanbul: Kültür Bakanlığı Yayınları, 1979.

Demiralp, Yekta. Akşehir ve Köylerindeki Türk Anıtları. bs. Ankara: Kültür Bakanlığı Yayınları, 1996.

Diğler, Mustafa ve Aydın, Seçkin. "Mardin'de Artuklu Dönemine Ait Taş İşçiliğinde Kullanılan Motiflerin Plastik Öğeleri”, I. Uluslararası Artuklu Sempozyumu 
Bildirileri, 25-26-27 Ekim 2007 Mardin, ed. İbrahim Özçoşar, Mardin Valiliği, (Mardin 2008), II, 349-381.

Doğan, Belkıs ve Doğanay, Aziz. “Akkoyunlu ve Karakoyunlu Devletlerinde Mimarî ve Sanat Üslûbu Üzerine Bir Değerlendirme". Insan ve Toplum Bilimleri Araştırmaları Dergisi, 6/1, (2017): 657-682.

Akkoyunlu Ve Karakoyunlu Türkmen Devletlerinde Mimarî Ve Sanat Üslûbu, Marmara Üniversitesi Sosyal Bilimler Enstitüsü Yüksek Lisans Tezi, İstanbul 2017.

Gabriel, Albert. Şarki Türkiye'de Arkeolojik Geziler, çev: İdil Çetin, Ankara: Dipnot Kitaplar1 2014.

Görür, Muhammed. Beylikler Dönemi Mimarisinde Taş Süsleme (1300-1435), Yayınlanmamış Doktora Tezi, Hacettepe Üniversitesi, Sosyal Bilimler Enstitüsü, Ankara 1999.

Göyünç, Nejat. XVI. Yüzyılda Mardin Sancă̆. bs. Ankara: Türk Tarih Kurumu, 1991.

Gündoğdu, Hamza. “ Gebze Çoban Mustafa Paşa Külliyesi'nin Osmanlı Külliyeleri İçindeki Yeri ve Önemi", Uluslararası Gazi Süleyman Paşa ve Kocaeli Tarihi Sempozyumu-III, Kocaeli: Kocaeli Büyükşehir Belediyesi Yayınları, (2017): 2781-2808.

Hill, Derek ve Graber, Oleg. Islamic Architecture and Its Decoration, A.D. 800-1500. bs. Londra: Faber and Faber, 1964.

İnal, Güner. “Orta Çağlarda Anadolu'da Çalışan Suriye ve Mezopotamyalı Sanatçılar". Sanat Tarihi Yıllı̆̆ı̆, XI: 83- 94. 1982.

Karaçam, Hüseyin. Artuklu Kitabeleri ( 1102-1409), Yayımlanmamış Yüksek Lisans Tezi, Marmara Üniversitesi Türkiyat Araştırmaları Enstitüsü, İstanbul 2012.

Karadaş, Şükriye. Anadolu Selçuklu Dönemi Mimarisinde Bitkisel Bezeme Unsûrları, Yayımlanmamış Doktora Tezi, Atatürk Üniversitesi, Sosyal Bilimler Enstitüsü, Erzurum 2011.

Karamağaralı, Beyhan. Ahlat Mezartaşları. bs. Ankara: Güven Matbaası, 1972.

Keleş, Hamza. "Anadolu'da Akkoyunlu Kültür Mirası; Tarihi Eserler", Türk Kültürü Ve Hacı Bektaş Veli Araştırma Dergisi, 38, (2006): 63-81.

Kodaş, Ergül. "Yukarı Dicle'de Yeni Bir Çanak Çömleksiz Neolitik Yerleşim Yeri: Boncuklu Tarla Kazıları ve İlk Gözlemler". Arkeoloji Ve Sanat Dergisi,157158, (2019): 7-20.

Meinecke, Michael. Die Memlukische Architectur in Agypten and Syrien 648/1250 bis 923/1517. bs., Glückstadt: Verlag J.J. Augustin GmbH, 1992.

Mülayim, Selçuk. Anadolu Türk Mimarisinde Geometrik Süslemeler, Selçuklu Çağı. bs. Ankara: Kültür ve Turizm Bakanlığı Yayınları, 1982.

Ödekan, Ayla. Osmanlı Öncesi Anadolu Türk Mimarisinde Mukarnaslı Portal Örtüleri. bs. İstanbul: İstanbul Teknik Üniversitesi Yayınları, 1977.

Ögel, Semra. Anadolu Selçukluları'nın Taş Tezyinatı. bs. Ankara: Türk Tarih Kurumu Basımevi, 1966.

"Taç kapılar", Anadolu Selçukluları ve Beylikler Dönemi Uygarlı̆̆ı 2. ed. Ali Uzay Peker ve Kenan Bilici, Ankara: Kültür ve Turizm Bakanlığı Yayınları, 2006, 469- 486.

Öney, Gönül. “Anadolu Selçuklu ve Beylikler Devri Ahşap Teknikleri”, Sanat Tarihi Yillı̆̆ı,3, (1969-1970): 137-149.

. Ankara Arslanhane Camii. bs. Ankara: Kültür Bakanlığı Yayınları, 1990. 
Öney, Gönül ve Erginsoy, İlker. Anadolu Selçuklu Mimari Süslemesi ve El Sanatları. bs. Ankara: İş Bankası Yayınları, 1992.

Özbek, Yıldıray. "Anadolu Türk Mimarisinde Taş Süsleme”. Türkiye Araştırmaları Literatür Dergisi, 7/14, (2009): 141-169.

Osmanlı Beyliği Mimarisinde Taş Süsleme (1300-1453). bs. Ankara: Kültür Bakanlığ1 Yayınları, 2002.

Semerci, Fatih. Mardin Kireçtaşının Yapı Taşı Olarak Araştııılması, Yayımlanmamış Yüksek Lisans Tezi, İstanbul Teknik Üniversitesi, Fen Bilimleri Enstitüsü, İstanbul: 2008.

Seyhan, Köksal. "Çoban Mustafa Paşa Külliyesi". Türkiye Diyanet Vakfi İslam Ansiklopedisi, 8, (İstanbul 1993): 351-354.

Soyukaya, Nevin vd., Mardin Kültür Envanteri, bs. İstanbul: Mardin Valiliği, Çekül Yayınlar1, 2013.

Sözen, Metin. Anadolu Medreseleri I, İstanbul: İstanbul Teknik Üniversitesi Yayınları, 1970.

. Anadolu'da Akkoyunlu Mimarisi. bs. İstanbul: Türkiye Turing ve Otomobil Kurumu, 1981.

Tuncer, Orhan Cezmi. "Artuklu Yapıları (yaptıran, yürüten ve yapanlar)", I. Uluslararası Artuklu Sempozyumu Bildirileri, 25-26-27 Ekim 2007 Mardin, ed. İbrahim Özçoşar, Mardin Valiliği, (Mardin 2008), II, 152.

. "Birkaç Selçuklu Taç Kapısında Geometrik Araştırmalar”. Vakıflar Dergisi, 16, (1982): 61-76.

. Diyarbakır Camileri. bs. Ankara: Diyarbakır Belediyesi Yayınları,1996.

Turan, Çimen. Artuklu Dönemi Tarihi Yapılarındaki Figürlü Süslemeler Ve Orta Asya Kültürünün Etkileri, Yayınlanmamış Yüksek Lisans Tezi, Batman Üniversitesi Sosyal Bilimler Enstitüsü, Batman 2014.

Uluçam, Abdüsselam. "İslam Dönemi Mardin'i", Taşın Belleği Mardin. 99-116, İstanbul: Yapı Kredi Yayınları, 2005.

Uysal, Ali Osman. “Adana Ulu Camii”. Vakıflar Dergisi, 19, (1985): 277-284.

Ünal, Rahmi Hüseyin. Osmanlı Öncesi Anadolu-Türk Mimarisinde Taç Kapılar. bs. İzmir: Ege Üniversitesi Yayınları, 1982.

Ünver, A. Süheyl. Mardin Mimari Anttlarında Tezyini Yorumlar. bs. İstanbul: Numune Matbaacilık, 2010.

Yeşilbaş Evindar. "Hamza-i Kebir Türbesi Üzerine Yeni Değerlendirmeler". Milel ve Nihal, 2, (2014): 163-182.

Yetkin, Şerare. "Sinan'ın Mimarisinde Çini Süsleme Düzeni”, Mimarbaşı Koca Sinan, Yaşadiğı Çağ ve Eserleri, ed. Sadi Bayram, İstanbul: Vakıflar Genel Müdürlüğü, 1988, 479-498.

Yıldız, Şenay Özgür. "Gaziantep Camilerinde Görülen Bazı Güneyli Etkiler". Ege Üniversitesi Sanat Tarihi Dergisi, 25/1, (2016): 86-110.

Yiğit, İsmail. Memlûkler. bs. İstanbul:Kayıhan Yayınları, 2015.

Yuvalı, Abdulkadir. “Artukoğulları Döneminde Mardin'deki Maddi Kültür Unsurları", I. Uluslararası Mardin Tarihi Sempozyumu, ed. İbrahim Özçoşar, Hüseyin Haşimi Güneş, İstanbul: Mardin Tarihi İhtisas Kütüphanesi Yayınları, 2006, 27-37. 


\section{Doi: 10.34247/artukluakademi.674407 | Araştırma Makalesi}

\section{Evindar Yeşilbaş}

\section{Marquetry Technique in Medieval Islamic Architecture Decoration Program: The Sample of Mardin}

Citation/@: Yeşilbaş, Evindar, Marquetry Technique in Medieval Islamic Architecture Decoration Program: The Sample of Mardin, Artuklu Akademi 2020/ 7 (1), 29-76.

\section{Extended Abstract}

Architectural decoration techniques vary according to the intervention applied on the building material surface. Stone has been used as a main building material for centuries not only due to geographical factors and durability, but also due to personal taste. Embossment, engraving, tracery, marquetry, damascene etching and engraining methods, and colored stones are used for stone decoration in architecture. Marquetry, which is the subject of our study, is a technique used to create decorative patterns by inserting materials of different colors on the building material.

This study focused on Islamic period historic buildings with stone-marquetry decorations in Mardin, such as Latifiye Mosque, Hamza-i Kebir Mosque, Zinciriye Madrasa and Kasımiye Madrasa. The objective of this study was to fill the gap in the literature on marquetry and to provide insight into the marquetry decorations of Islamic buildings in Mardin. To this end, this study briefly addressed the historical and architectural characteristics of marquetry, and then, explained on which parts of those buildings it was used, and then, described the patterns and motifs in detail.

Colored stones are widely used for decoration in historic buildings. Different colors are widely used in buildings of the same period in different regions of Anatolia both as marquetry and alternately in arches. Engraving, kundekari, and tracery were used by Central and South Anatolian principalities for stone decoration; while colored stones, tiles, glazed brick marquetry, and mosaic techniques were used by Western Anatolian principalities. Some of the engraving, embossment, damascene etching, engraining, marquetry, and alternating techniques were used simultaneously for the Ottoman stone decoration during the period of the principalities. However, the facade arrangements and decoration of the historic buildings had local characteristics which varied across principalities. For instance, the historic buildings in Mardin were decorated with colorful stones- this supports our view. In Mardin, yellowish limestone is the main building material due to geographical conditions. It is believed that two-colored stone decoration and marquetry were especially used to break monotony in terms of decoration and to make a lasting impression on spectators.

Our analysis showed that marquetry was used by the Artuklu and Akkoyunlu states in Mardin for decoration. These both states used similar decorative architectural techniques, probably due to the transmission of art culture. These decorations can be first observed in the Artuklu buildings and bear a close 
resemblance to the Zengi and Ayyubid art in connection with political connections and geographical proximity. This artistic similarity shows that marquetry may not be limited to Anatolia but may have been commonly used in Syria and Iraq as well. Decorations based on different cultures and belief codes in the regions under the reign of the Artuklu and Akkoyunlu show that a wider geographical perspective should be taken into account when addressing marquetry.

The colored stone decoration that we encounter in the architecture of southern countries, such as Syria and Egypt, can be associated with the Mamluk art as well. The Mamluks took over the architectural heritage of Ayyubi, Zengi, Fatimi and Tulunids established in Syria and Egypt in the pre-Mamluk period. When we compare their cultural heritage with that of Anatolia, we see that the latter is more of a monumental character. Even so, the two styles bear decorative similarities as a tangible indicator of cultural and artistic interaction.

Two materials were used to apply marquetry on the Islamic period buildings in Mardin. The first and only example is the glazed tile material applied to stone in Hamza-i Kebir Tomb. The second example is the marquetry of a stone of different colors onto yellowish limestone in Latifiye Mosque, Kasımiye Madrasa, and Zinciriye Madrasa. The marquetry decorations are of geometric, and have motifs of plants and scripts. The geometric patterns consist of multi-armed star, triangle, and polygon motifs; the plant ornaments consist mostly of palmette motifs; and the texts are of kufic form of calligraphy.

Zinciriye and Kasımiye Madrasas have decorations of portals, arches, and masjid spaces with similar characteristics. At first sight, the fine stonework in the portals and the common technique used in the marquetry decorations draw the attention. These two buildings mostly have motifs of plants. Both the form and the marquetry materials of the palmette motifs in the madrasas are very similar. This shows that palmette is highly preferred and used either as the main or complementary motif in the decoration composition in Mardin.

Many construction elements of the Artuklu period Mardin Mosques, such as mihrab, arch, window jambs, have alternative two-colored stone decorations. Marquetry was used only on the portal of Latifiye Mosque. It is noteworthy that Latifiye Mosque is the only Artuklu period Mosque on which marquetry was used.

Similar subjects and design and forms of composition, and marquetry of dark stone on yellowish limestone suggest the presence of a powerful masonry workshop in Mardin between the thirteenth and fifteenth centuries. This is also confirmed by the fact that the marquetry characteristics of the decoration programs of the Artuklu period Latifiye Mosque and Zinciriye Madrasa are similar to those of the Akkoyunlu period Kasımiye Madrasa.

Of the Islamic period historic buildings in Mardin, the portal of Hamza-i Kebir Mosque is a unique example of marquetry applied to the stone surface of the ceramic pieces of tile mosaic technique. 
In conclusion, the decoration programs of some of the medieval Islamic period Artuklu and Akkoyunlu buildings in Mardin have marquetry decorations. These architectural structures have unique marquetry decorations with local characteristics. They are fine examples of the medieval Islamic art. The architectural structures in Mardin have much more marquetry decorations than the other architectural structures of the same period in Anatolia. The marquetry decorations in the architectural structures in Mardin reflect the characteristics of the Seljuk decoration style in motifs and compositions. 
